九州大学学術情報リポジトリ

Kyushu University Institutional Repository

\title{
Synopsis of Andrena (Andrena) of Japan (Hymenoptera, Andrenidae) Part I
}

Tadauchi, 0samu

Entomological Laboratory, Faculty of Agriculture, Kyushu University

Hirashima, Yoshihiro

Entomological Laboratory, Faculty of Agriculture, Kyushu University

Matsumura, Takeshi

National Grassland Research Institute

https://doi.org/10.5109/23832

出版情報 : 九州大学大学院農学研究院紀要. 31 (1/2)，pp.11-35，1987-02. Kyushu University バージョン：

権利関係 : 


\title{
Synopsis of Andrena (Andrena) of Japan (Hymenoptera, Andrenidae) Part $\mathbf{I}^{1,2)}$
}

\author{
Osamu Tadauchi*, Yoshihiro Hirashima* and Takeshi Matsumura ${ }^{\dagger}$ \\ * Entomological Laboratory, Faculty of Agriculture, \\ Kyushu University 46-01, Fukuoka 812 \\ † National Grassland Research Institute, Nishinasuno, \\ Tochigi 329-27
}

(Received May 27, 1986)

\begin{abstract}
Japanese species of the subgenus Andrena Fabricius of the genus Andrena are revised. Sixteen species are recognized, including 3 new species and 1 newly recorded species. In this paper (Part I ) nine species are treated. Two new species, Andrena (Andrena)mali and A. (A.) sakagamii are described and A. (A.) apicata Smith is recorded from Japan for the first time, and is represented by a new subspecies, A. (A.) apicata aino. Andrena (A.) bombiformis Yasumatsu et Hirashima is synonymized with A. (A.) nawai Cockerell based on color variation in female hairs and male morphological characters. A color variation of the hairs in A. (A.) mikado Strand et Yasumatsu is figured and tabled. A key is presented for the Japanese species of Andrena (Andrena). The distribution map, floral records and flight records of each species are presented.
\end{abstract}

\section{INTRODUCTION}

The subgenus Andrena of the genus Andrena is widely distributed in both the New and Old Worlds. Females of this subgenus are characterized by the marked humeral ridge on the pronotum, the well developed propodeal corbicula, and the medially elevated pygidial plate with lateral sharp edges. Males are recognizable by the large head, the long, curled, falciform mandibles which have a ventral projection near the base in most cases, the angled genal area, and the marked humeral ridge on the pronotum. The species of this subgenus are usually hairy.

Lanham (1949) and LaBerge (1964) studied the subgenus of the New World, and Hedicke (1933) and Warncke (1968) treated the subgenus in the subgeneric classification of the west Palaearctic Region. As to the Japanese species of the subgenus Hirashima recorded one species in 1953 and 1957, respectively. Later in 1962 he studied the subgenus of Japan and recognized 13 species including 8 new species.

In this paper we examined specimens newly gathered throughout Japan and found 3 new species and 2 new subspecies. Andrenabombiformis Yasumatsu et Hirashima

1) Partly supported by a grant (1984) from the Japan Society for the Promotion of Science, Tokyo.

2) Contribution from the Entomological Laboratory, Faculty of Agriculture, Kyushu University, Fukuoka (Ser. 3, No. 212). 
is recognized as a new synonym of A. (A.) nawai Cockerell which is revealed to show a wide range of color variations of the hairs, as shown in A. (A.) mikado Strand et Yasumatsu. Andrena (A.) shirozui Hirashima is reduced to the subspecies of A. lapponica Zetterstedt. The males of A. (A.) lapponica shirozui Hirashima and A. (A.) maukensis Matsumura are described for the first time. The male morphological differences between 1 st and 2nd generations in Andrena (A.) ishiharai Hirashima are described.

\section{Subgenus Andrena Fabricius, 1775}

Andrena Fabricius, 1775, Syst. ent. : 376 ; Lanham, 1949, Univ. Calif. Publ. Ent., 8 : 205 ; Hirashima, 1962, J. Fac. Agr., Kyushu Univ., 12 : 123 ; Wamcke, 1968, Mem. Est. Mus. Zool. Univ. Coimbra, (308) : 101.

Anthocharessa Gistel, 1850, Isis, $6: 82$.

Type species : Andrena helvola (Linnaeus, 1758) (by designation of Viereck, 1912).

\section{Key to JAPANESE SPECIES OF Andrena (Andrena) \\ Females}

1. Tibial scopa rather short to short, fine

Tibial scopa composed of rather coarse to coarse, long hairs

2. Hind tibia widened apically with anterior margin emarginate ; hairs on clypeus not dense, weakly plumose; process of labrum not emarginate

brevihirtiscopa Hirashima

Hind tibia normal ; hairs on clypeus dense, strongly plumose ; process of labrum emarginate ….................. mali Tadauchi et Hirashima, n. sp.

3. Tibial scopa, femoral floccus, and trochanteral floccus not mixed with

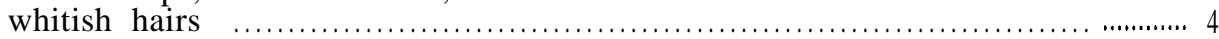

Tibial scopa including whitish hairs, at least trochanteral floccus whitish

4. Large species, length $13-15 \mathrm{~mm}$; clypeus elongate, much exceeding line running bases of eyes ; tibial scopa with coarse, rather loose hairs ; hairs on head, thorax and metasomal terga long, dense ; color of hairs variable, fulvous to fuscous (Fig. 48) …............. mikado Strand et Yasumatsu Smaller, length about $12 \mathrm{~mm}$; clypeus not elongate ; tibial scopa compact

5. Hind tibia and tarsus brown, tibial scopa fuscous ; clypeus tessellate all over with a narrow, impunctate, median space ; hairs on head fuscous, those on thorax fulvous above, fuscous below ................ ishiharai Hirashima Hind tibia and tarsus reddish brown to ferruginous; tibial scopa orange ; clypeus tessellate only basally, broadly shiny and smooth with a broad, impunctate, median space, hairs on head, thorax, and meta. somal terga long, dense ; color of hairs variable, fulvous to fuscous (Fig. 57) .......................................... nawai Cockerell (=bombiformis $)$

6. Mesoscutum broadly nearly smooth medially, therefore shiny, weakly 
punctate ; clypeus sparsely, coarsely and strongly punctate ; hairs on head pale and fuscous, those on thorax nearly fulvous above, paler below, mixed with sparse, brownish ones on mesoscutum ….. esakii Hirashima

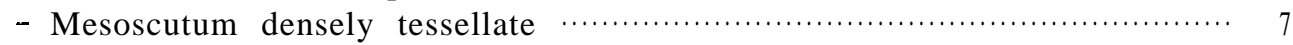

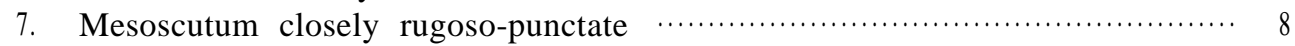

- Mesoscutum sparsely and shallowly punctate or nearly impunctate …...........9

8. Large species, about $10.5 \mathrm{~mm}$; clypeus coarsely punctate ; caudal fimbria brown; central Honshu and Shikoku …........ saragamineensis Hirashima Smaller, about 8.5-9.5 $\mathrm{mm}$; clypeus weakly punctate ; caudal fimbria pale yellow ; Hokkaido and northern Honshu . . sakagamii Tadauchi et al., n. sp.

9. Clypeus with rather dense, whitish hairs ; clypeus tessellate nearly all

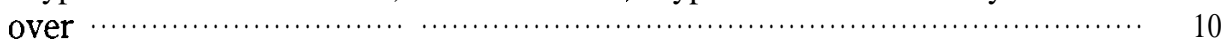

- Clypeus with sparse hairs ; clypeus tessellate basally, at least smooth and shiny medio-apically

10. Larger, length about $12-13 \mathrm{~mm}$; tibial scopa narrowly whitish in front, broadly brownish behind ; process of labrum very small ; clypeus dirty whitish intermixed with brownish hairs medially

apicata aino Tadauchi et al., n. ssp.

- Smaller, length about $10 \mathrm{~mm}$; tibial scopa broadly sooty whitish in front, narrowly brownish behind; clypeus with sooty white hairs, not intermixed with brownish ones medially ..................... hondoica Hirashima

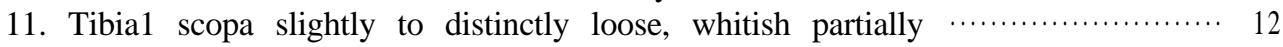

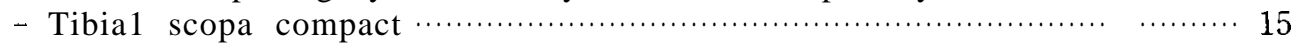

12. Hind tibia very long, basal half of propodeal enclosure rugose ; clypeus tessellate on a basal half, with a narrow, impunctate space ; hairs on head whitish, those on thorax dirty whitish to pale fulvous ; tibia1 scopa whitish in front, fuscous below …........................ longitibialis Hirashima

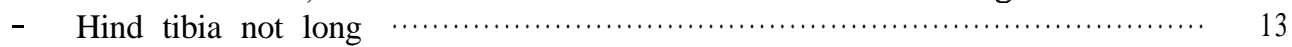

13. Clypeus tessellate on at least basal half, with a narrow, median, impunctate space ; malar space auout $1 / 4$ times as long as base of mandible ; hairs on head primarily sooty whitish to yellowish ; tibial scopa broadly whitish to yellowish in front, brownish above ; caudal fimbria pale

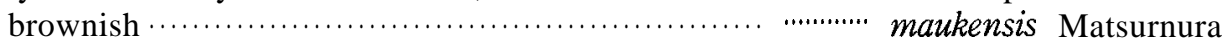

Clypeus broadly smooth and shiny, very narrowly tessellate basally with a broad, median, impunctate space ; clypeus sparsely punctate ; malar space about $1 / 3$ times as long as base of mandible ; hairs on head primarily fuscous ; tibial scopa white in front and slightly brownish behind ; caudal fimbria deep brown

14. Hairs on vertex and antennal region black, mixed with whitish hairs; mesepisternum without fuscous hairs; Hokkaido and northern Honshu lapponica shirozui Hirashima, n. stat.

- Hairs on vertex and antennal region black, not mixed with whitish ones ; mesepisternum with much fuscous hairs ; central Honshu

lapponica sumizome, Tadauchi et al., n. ssp.

15. Larger, length about $10-11 \mathrm{~mm}$, thorax intermixed with brown to black hairs ; clypeus strongly convex with a broad, shiny, impunctate space 

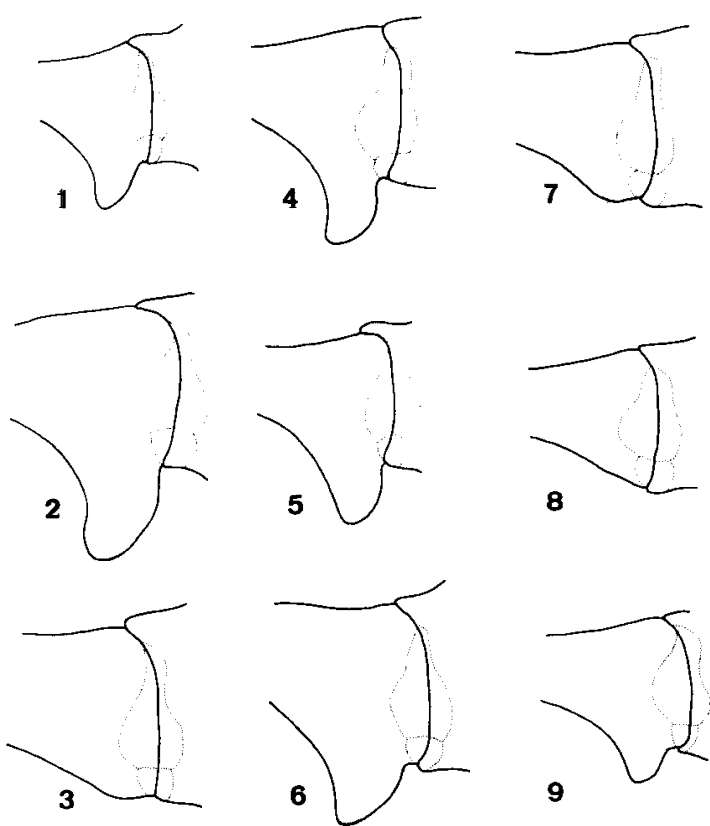
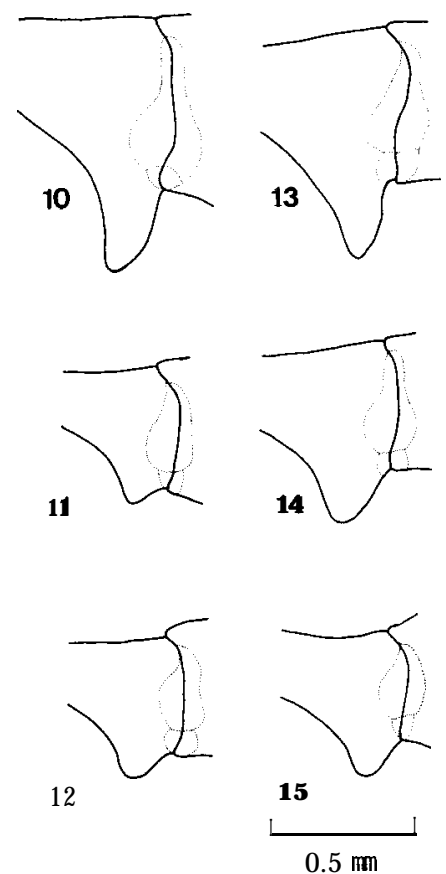

Figs. 1-15. Ventral projections near the base of mandibles in males of 15 species of the Japanese Andrena (Andrena), 1 :brevihirtiscopa, 2 : mikado, 3: ishiharai, 4 : nawai, 5 : esakii, 6 : saragamineensis, $7:$ sakagamii, 8 : apicata aino, 9 : hondoica, 10 : Iongitibialis, 11 : maukensis, 12 : lapponica shirozui, 13 :aburana, 14 : benefica, 15 : babai.

subapically ; tibial scopa broadly brownish in front, narrowly whitish behind aburana Hirashima

Smaller, length about $9.5 \mathrm{~mm}$; tibial scopa nearly whitish or narrowly brownish behind

16. Clypeus less convex, tessellate on basal half and smooth and shiny on apical half, with very sparse punctures which are irregular in size and distribution benefica Hirashima

Clypeus strongly convex, tessellate on basal $1 / 3$ and very weakly tessellate on apical half, with roughened, denser and stronger punctures babai Tadauchi et Hirashima, n. sp.

Males

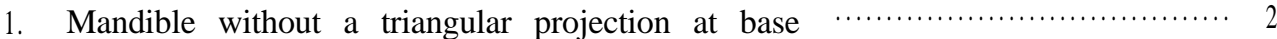
Mandible with a triangular projection at base

2. Malar space about $1 / 4$ times as long as base of mandible ; hairs on clypeus fuscous, those on thorax fulvous ; 2 generations a year ; Hok- 

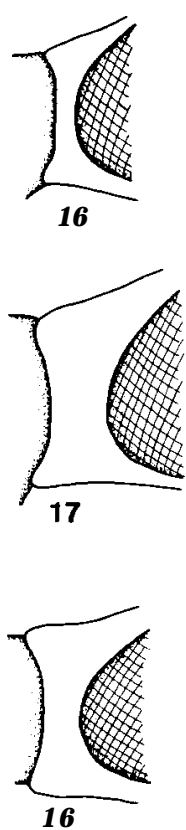
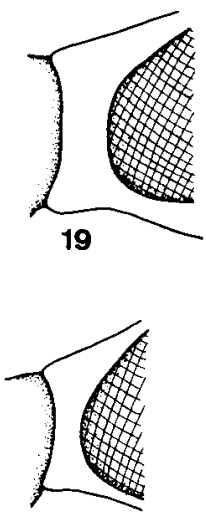

20

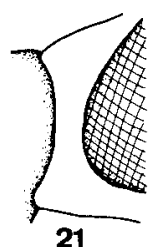

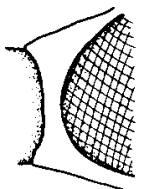

22

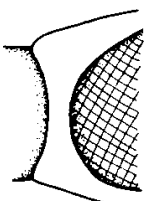

23

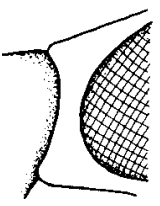

24
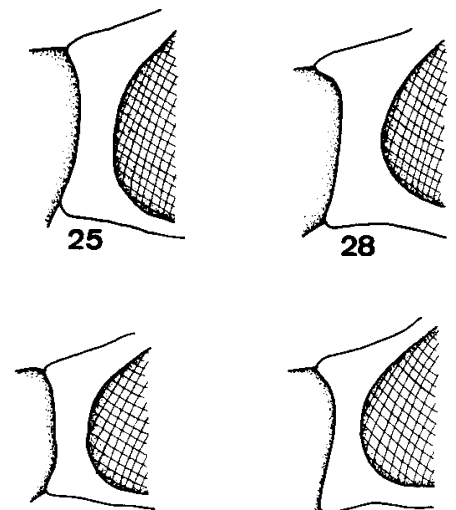

26
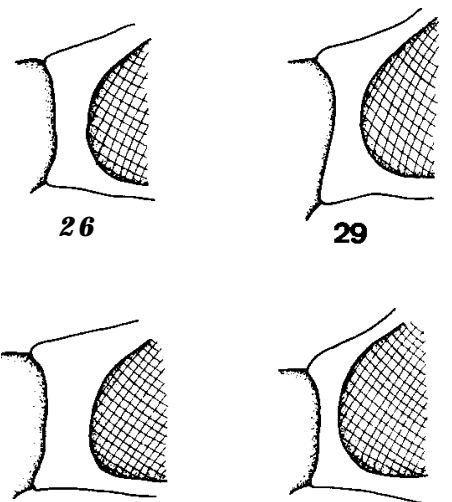

27

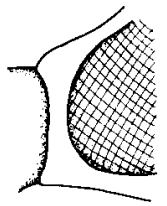

30

$0.5 \mathrm{~mm}$

Figs. 16-30. Malar spaces in males of 15 species of the Japanese Andrena (Andrena), 16: brevihirtiscopa, 17: mikado, 18: ishiharai, 19: nawai, 20: esakii, 21 : saragamineensis, 22 : sakagamii, 23 : apicata aino, 24 : hondoica, 25: longitibialis, 26: maukensis, 27 : lapponica shirozui, 28 :aburana, 29 : benefica, 30 : babai.

kaido, Honshu, Shikoku ishiharai Hirashima Malar space very narrow, about $1 / 6$ times as long as base of mandible ; hairs on clypeus whitish to yellowish, dense, those on thorax white ;1 generation a year

3. Larger, length about $9.5 \mathrm{~mm}$; clypeus rugoso-punctate, tessellate on basal half ; hairs on head and thorax white, dense ; mesoscutum densely tessellate, nearly impunctate; hairs on metasomal tergum 6 whitish ; metasomal sterna 2-5 without distinct, long, curled fringes apically apicata aino Tadauchi et al., n. ssp. Smaller, length 8-9 mm ; clypeus tessellate on basal $1 / 6$, smooth and shiny apically ; hairs on head and thorax pale yellowish to fulvous ; mesoscutum weakly tessellate with shallow punctures; hairs on metasomal tergum 6 golden ; metasomal sterna 2-5 each with a long, curled, fulvous fringe apically .................... sakagamii Tadauchi et al., n. sp.

4. Flagellar segment 1 longer than 2 ....................................................... 5

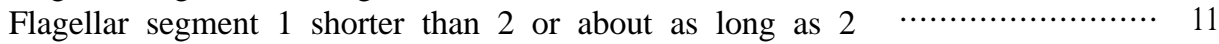

5. Malar space long, more than $1 / 4$ times as long as base of mandible ……..... 6

- Malar space short, less than $1 / 4$ times as long as base of mandible $\cdots \cdots \cdots \cdots . . . . .8$ 
6. Large species, length over $10 \mathrm{~mm}$; clypeus strongly exceeding line running bases of eyes, distinctly narrowing toward apex ; clypeus nearly flat, distinctly punctate ; posterior margins of metasomal sterna each with a long, fringe of well, curled, whitish hairs

mikado Strand et Yasumatsu

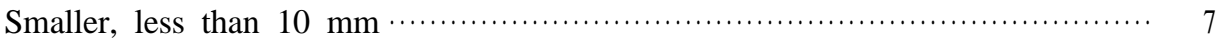

7. Clypeus without an impunctate space medially ; clypeus nearly flat, nearly smooth, shiny with distinct punctures all over ; hairs on clypeus and thorax fulvous ; those on metasomal tergum 6 golden ; posterior margins of metasomal sterna each with a long fringe of well curled, fulvous hairs

naw ai Cockerell

Clypeus with a wide, impunctate, median space apically ; clypeus strongly convex subapically, tessellate on basal 1/6; hairs on clypeus pale yellowish, those on thorax pale yellowish mixed with fuscous ones, those on metasomal tergum 6 brownish; posterior margins of metasomal sterna without long, curled fringes ..................... aburana Hirashima

8. Clypeus well convex, without dense, white hairs $\ldots \ldots \ldots \ldots \ldots \ldots \ldots \ldots \ldots \ldots \ldots \ldots$

Clypeus nearly flat medially, with dense, white hairs subapically $\cdots \cdots \cdots \cdots \cdots \cdots \cdots \cdots \cdots$

9. Clypeus longitudinally convex ; hairs on thorax yellowish, those on genal area fuscous above, whitish below; mesoscutum densely tessellate with shallow punctures; enclosure of propodeum rugose on basal half ; genal area gradually angled behind longitibialis Hirashima Clypeus transversely convex ; hairs on thorax yellowish intermixed with or without black ones, those on genal area fuscous all over ; mesoscutum weakly tessellate with shallow punctures ; enclosure of propodeum rugose on basal $1 / 3$; genal area distinctly angled behind

esakii Hirashima

10. Clypeus with a broad, impunctate, median space, which is sometimes rising ; clypeus weakly tessellate basally or nearly smooth and shiny all over ; hairs on genal area fuscous above, white below ; mesoscutum moderately tessellate with shallow punctures ; enclosure of propodeum rugose on basal half; metasomal sterna with well curled, long fringes

saragamineensis Hirashima

- Clypeus without an impunctate, median space; clypeus smooth and shiny medially, tessellate elsewhere ; hairs on genal area fuscous all over ; mesoscutum densely tessellate, impunctate ; mesoscutellum shiny and smooth anteriorly ; enclosure of propodeum rugose only basally ; metasomal sterna with sparse, short hairs posteriorly

brevihirtiscopa Hirashima

11. Clypeus with close roughened punctures all over and covered entirely with dense, white hairs

hondoica Hirashima

- Clypeus punctate, but sparsely so on median portion, without dense, white hairs

12. Clypeus well producing apically ; flagellar segment 1 shorter than 2 ; mesoscutellum tessellate all over ; summer species ; mountainous region 

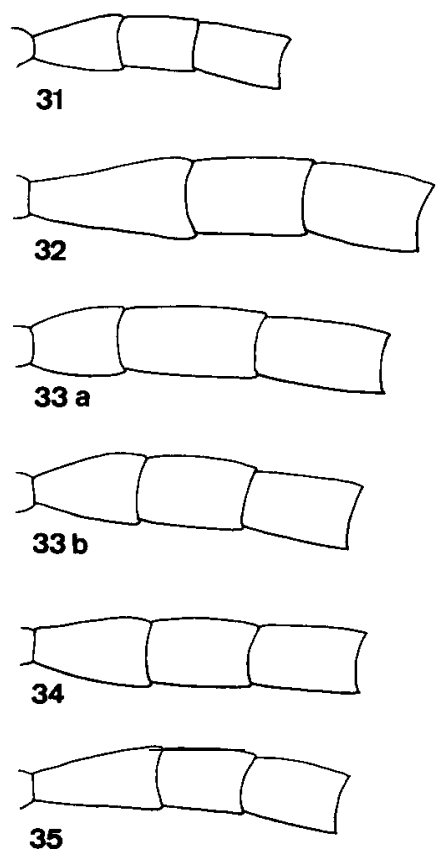
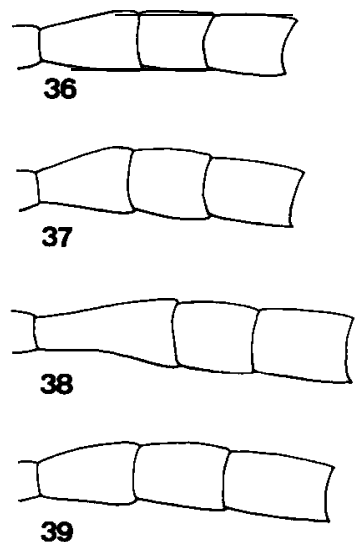

39

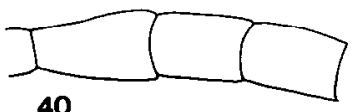

40

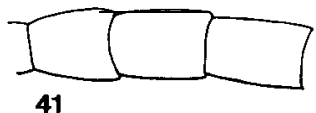

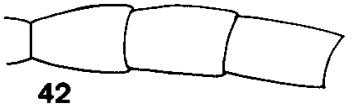

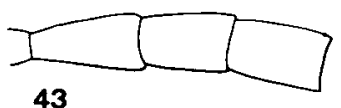

43
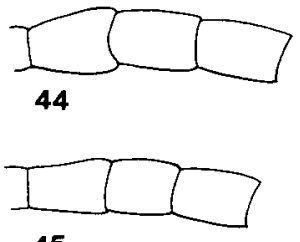

45

$0.5 \mathrm{~mm}$

Figs. 31-45. First to 3rd flagellar segments in males of 15 species of the Japanese Andrena (Andrena), 31 :brevihirtiscopa, 32 : mikado, 33a: ishiharai, 1st generation, $33 \mathrm{~b}$ : the same, 2nd g., 34 : nawai, 35 : esakii, 36 : saragamineensis, 37 :sakagamii, 38 : apicata aino, 39 : hondoica, 40 : longitibialis, 41 : maukensis, 42 : lapponicashirozui, 43 : aburana, 44 : benefica, 45 : babai.

Clypeus less producing; flagellar segment 1 nearly as long as 2, mesoscutum smooth and shiny anteriorly ; spring species

13. Malar space short, about $1 / 6$ times as long as base of mandible ; flagellar segment as long as broad, much shorter than 2 ; clypeus without an impunctate, median space ; hairs on genal area black near eye, rest of space whitish; metasomal tergum 6 with pale yellowish hairs

maukensis Matsumura

Malar space long, about $1 / 3$ times as long as base of mandible ; flagellar segment 1 longer than wide, which is slightly shorter than 2 ; clypeus with a median, impunctate space ; hairs on genal area fuscous all over ; metasomal tergum 6 with whitish hairs

lapponica shirozui Hirashima, n. stat,

14. Hairs on clypeus dull whitish to yellowish intermixed with brownish to fuscous ones; those on outer face of propodeum pale yellowish mixed

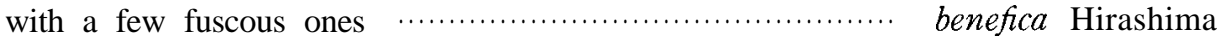
Very similar to the preceding, but hairs on clypeus silvery, not intermixed with fuscous ones; those on outer face of propodeum mixed

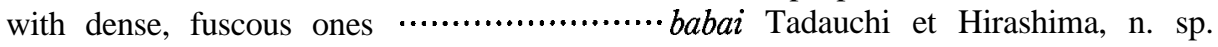




\section{Andrena (Andrena) brevihirtiscopa Hirashima}

(Figs. 1, 16, 31, 46, 94, Table 4)

Andrena (Andrena) brevihirtiscopa Hirashima, 1962, J. Fac. Agr., Kyushu Univ., 12 : 124, female \& male ; Hirashima, 1966, ibid., 14 : 100 and 116.

Distribution : Japan (Hokkaido, Honshu, Sado Is., and Kyushu). (Fig. 46)

Floral records : 49 females and 16 males have been collected on 7 plants as follows : Rosaceae : Prunus Sargentii Rehd. (1 우); P. yedoensis Matsum. (1 우); Malus pumila Mill. (2우). Aceraceae : Acer sp. (42우9 $\left.\sigma^{7}\right)$. Cruciferae : Brassica Napus L. (5 ๙). Compositae : Petasites japonicus subsp. giganteus Kitam. $\left(2 \sigma^{\top}\right)$. Salicaceae : Salix sp. $(1 \mathrm{P})$.

Flight records : Female : late April to early May (Kyushu); late April to mid June (Honshu) ; early May to mid June (Hokkaido). Male : late April to early May (Kyushu) ; late April to late May (Honshu) ; late April to mid May (Hokkaido).

Specimens examined : We have examined 54 females and 36 males. Some of them are cited as follows : HOKKAIDO : 1 오, Ashibetsu-ko, Ashibetsu, 22. v. 1984 (0. Tadauchi) ; 16, Kakkumi, Oshima, 24. iv. 1977 (H. Fukuda) ;1 $\sigma^{7}$, Matsukurazawa, Hakodate, 24. iv. 1960 (K. Munakata) ;1 ð', Mt. Daisengen, Matsumae, 16. v. 1969 (S. Miura \& M. Komatsu). HONSHU :3 $\sigma^{7}$, Yorii, Saitama Pref., 5. iv. 1971 (T. Nanbu) ; $2 \sigma^{7}$, Okumiomote, Asahi, Niigata Pref., 16. v. 1985 (K. Baba) ; $1 \sigma^{7}$, Hatahoko, Mt. Norikura, Gifu Pref., 8. v. 1976 (0. Tadauchi) ;2 Pref., 6. v. 1979 (I. Togashi); 1 오, Sunayama, Ohno, Fukui Pref., 9. v. 1971 (Y. Haneda) ; $4 \sigma^{7}$, Taishaku-kyo, Hiroshima Pref., 30. iv. 1978 (H. Makihara). SADO IS. :1우, Shimokuchi, Ryotsu, 25. v. 1983 (K. Baba). KYUSHU : Mt. Hikosan, Fukuoka Pref. : 7 우 $2 \Im^{\nearrow}$, 27. iv. 1973 (M. T. Chûjô);3ð, 24. iv. 1975 (K. Takeno);14 우, 30. iv. 1975 (K. Ôhara); 11 우, 4. v. 1976 (K. Ôhara);5 5 , Mt. Daisen, Mts. Kuju, Oita Pref., 12. v. 1978 (Y. Hirashima).

Other localities (*new records): Ashoro, *Asahikawa, Sapporo, Narukawa, Hakodate (Hokkaido) ; Towada, *Shimokita (Aomori Pref.) ; Mt. Chokai (Yamagata Pref.) ; *Masutomi (Yamanashi Pref.) ; Senami, Sasagamine (Niigata Pref.) ; *Kawachi-mura (Ishikawa Pref.) ; Fukui, Eiheiji, Katsuyama, Izumi, Ikeda, Imajo (Fukui Pref.).

\section{Andrena (Andrena) mali Tadauchi et Hirashima, new species}

(Figs. 46, 94, Talbe 4)

This is a unique species in our fauna. It is somewhat similar to Andrena (Andrena) hondoica Hirashima. But the recognition of it is easy owing to the following characters: the tibial scopa rather small, composed of short, fine hairs; the head broader than long; the clypeus very narrowly tessellate basally and broadly smooth and shiny apically; the clypeus with dense, dirty white, plumose hairs all over. This species was collected in mid May in Tochigi Pref., central Honshu. It was taken on the flower of Malus pumila Mill.

Female : Length 8.5-9.0 mm.

Integumental color : Flagellar segments beneath brownish ; posterior margins of metasomal terga yellowish brown subhyaline. 


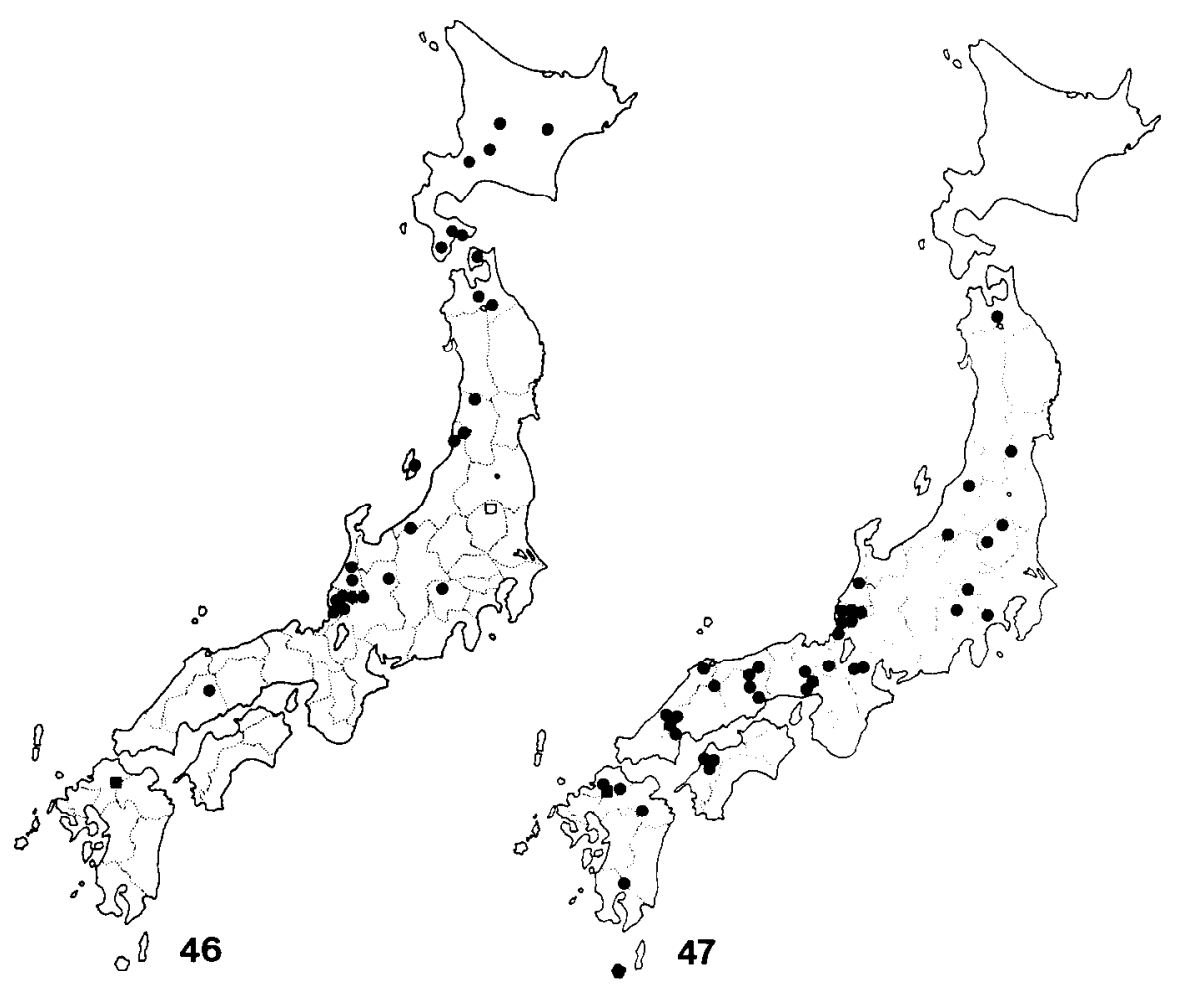

Figs. 46-47. Maps showing the distributions of Andrena (Andrena) brevihirtiscopa Hirashima, (black) and A. (A.) mali, new species (white) (46) and A. (A.) mikado Strand et Yasumatsu (47). A square indicates the type locality.

Pubescence : Hairs on head and thorax short, dense, those on clypeus strongly plumose, dirty white all over, those on paraocular area, frons, genal area near eye and vertex whitish, not mixed with blackish ones ; facial fovea bright brown above, paler below; facial fovea with upper end occupying $3 / 4$ of space between eye and post ocellus ; hairs on mesoscutum pale yellowish ; those on mesoscutellum yellowish, not intermixed with blackish ones; propodeal corbicula perfectly developed with well curled, long hairs anteriorly ; trochanteral floccus and femoral floccus white ; tibial scopa rather small, composed of short, fine hairs, tibial scopa whitish in front, pale brownish behind ; hairs on metasomal terga scanty, tergum 1 long, erect to suberect, terga 2-5 short ; terga 2-3 each with a loose, obscure, hair band on each posterior margin; caudal fimbria brown.

Structure : Head broader than long ; process of labrum emarginate in the middle ; malar space about $1 / 5$ times as long as base of mandible ; clypeus very narrowly tessellate basally and broadly smooth and shiny apically with strong, dense punctures ; clypeus with a narrow, longitudinal, impunctate space; mesoscutum weakly tessellate and weakly shiny in the middle with shallow, sparse punctures ; mesoscutellum broad- 
ly smooth and shiny with very sparse punctures anteriorly, and weakly tessellate posteriorly ; dorsal face of propodeum densely tessellate ; enclosure ill defined, rugose only basally, broadly tessellate apically; mesepisternum densely tessellate ; metasomal terga densely tessellate, nearly impunctate, posterior depressions of metasomal terga narrow, not well indicated.

Distribution : Japan (central Honshu). (Fig. 46)

Floral record : Malus pumila Mill.

Flight records : Female : mid May.

Type material : Holotype female (Type No. 2579, Kyushu Univ.), Apple Farm, Kuroiso, Tochigi Pref., 14. v. 1965 (E. Katayama). Paratype : 1 ㅇ, same locality and collector as holotype, 13. v. 1965.

Type depository : The type is preserved in the collection of the Entomological Laboratory, Faculty of Agriculture, Kyushu University.

\section{Andrena (Andrena) mikado Strand et Yasumatsu}

(Figs. 2, 17, 32, 47, 48, 94, Tables 1, 2, 4)

Andrena (Melandrena) mikudo Strand et Yasumatsu, 1938, Mushi, $11: 67$, female (not for male). Andrena mikado Yasumatsu, 1941, Peking Nat. Hist. Bull., 15: 278.

Andrena (Andrena) mikado Hirashima, 1962, J. Fac. Agr., Kyushu Univ., 12: 127, female \& male;

Hirashima, 1966, ibid., $14: 101$ and 116.

Hirashima (1962) pointed out that the female of this species shows a considerable variation in the color of the pubescence. Figure 48 shows the variation of hairs in this species. A typical fulvous form (forma A, Hirashima, 1962), which is coded as 111111 in the figure, is completely connected with a typical black form forma B, Hirashima, 1962) coded as 465653 by some intermediate forms. Tables 1 and 2 show the degree of the variation and its distribution. It seems that there is a tendency to similar color of the pubescence in the same area. However, it is notable that a few populations have a considerable variation such as those in Matsue, Shimane Pref. (221111 to 465653), Hiroshima (111111 to 465632) and Fukuoka (111111 to 465653). If the sample size is increased, it may proved that a wide variation of the color exists within every population.

Distribution : Japan (Honshu, Shikoku, Kyushu and Yakushima Is.). (Fig. 47)

Floral records : Hirashima (1962) recorded Pieris japonica. We examined 52 females and 8 males collected on 7 plants as follows : Ericaceae :Pieris japonica D. Don (45 우7 $\left.\sigma^{7}\right)$; Rhododendron pentaphyllum Maxim. (2 우); $R$. metternichii Sieb. et Zucc. (1우); R. sp. (2); Enkianthus perulatus Schneid. (1우). Compositae: Taraxacum japonicum Koidz. (1우). Salicaceae : Salix sp. (1 $\left.10^{\top}\right)$.

Flight records : Female : late March to mid May (Kyushu) ; late March to late May (Honshu). Male : late March to late April (Kyushu); early to late April (Shikoku); late March to late May (Honshu).

Specimens examined : We have examined 94 females and 150 males. Some of them are cited as follows : HONSHU : 1 우, Chuzenji, Nikko, Tochigi Pref., 11. v. 1976 (0. Tadauchi) ; 46, Mt. Mitsumine, Saitama Pref., 1. v. 1965 (T. Nanbu) ; 1 ㅇ, Sakasamaki, Niigata Pref., 1. vii. 1956 (K. Baba) ; 16, Nomidani, Kawachi-mura, Ishikawa Pref., 29. iv. 1962 (I. Togashi);2 오, Mt. Gozaisho, Mie Pref., 12. v. 1975 (0. Tadauchi) ; 16, 
A
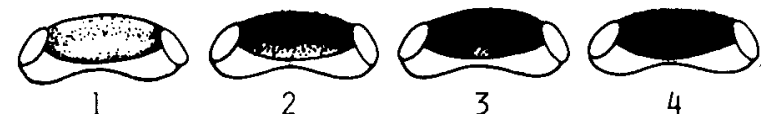

B
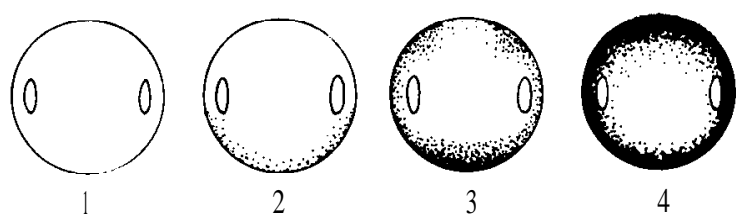

4

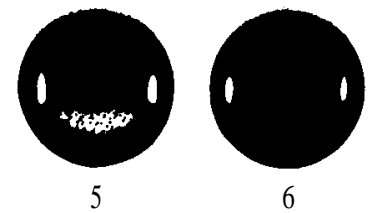

C
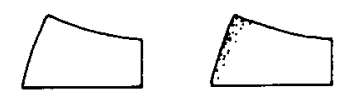

2

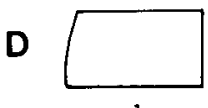

1

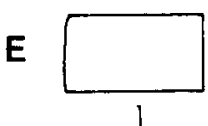

1

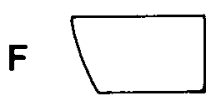

1

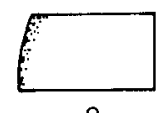

2
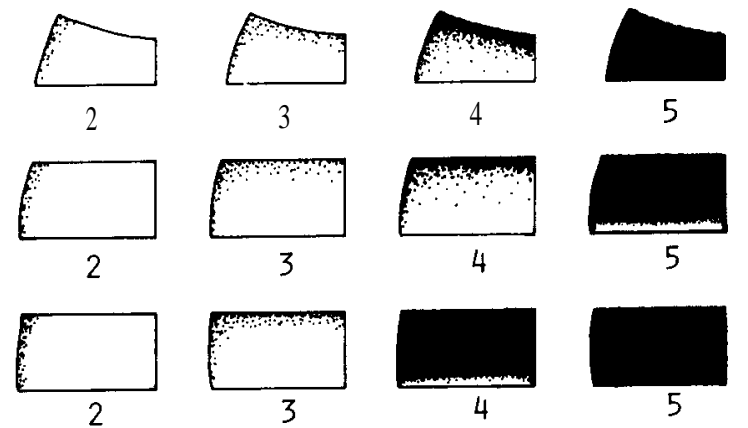

3

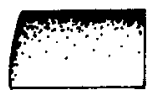

4
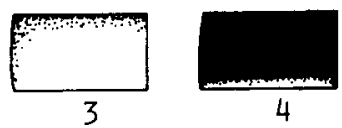

4

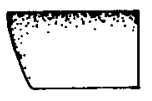

3
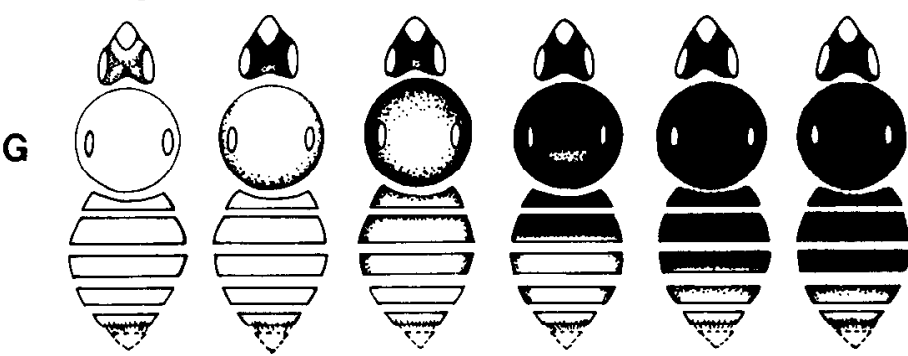

48

Fig. 48. Variation of color of the hairs in the female of Andrena (Andrena) mikudo, A: vertex, B: thorax including propodeum, C: 1st metasomal tergum, D: 2nd metasomal tergum, E: 3rd metasomal tergum, F: 4th metasomal tergum, G: some representative types in color of hairs.

Tsuyama, Okayama Pref., 12. iv. 1965 (T. Ono) ; 1 오, Mt. Nagi, Tottori Pref., 26. iv. 1976 (0. Tadauchi) ; 12 우, Mt. Makuragi, Matsue, Shimane Pref., 22. iv. 1982 (Y. Ono); 3우, Togouchi, Hiroshima Pref., 6. iv. 1986 (0. Tadauchi) ;2 우, Mt. Dogo, Hiroshima Pref., 25. iv. 1976 (0. Tadauchi). SHIKOKU :2우, Kuma, Ehime Pref., 15. iv. 1976 ( 0 . Tadauchi) ; $1 \sigma^{7}$, Takahama, Matsuyama, Ehime Pref., 3. iv. 1953 (M. Miyatake). KYUSHU :1우, Wakasugiyama, Fukuoka City, 11. v. 1973 (Y. Yoneda) ; Mt. Kuju, Oita Pref. :2 우, 11. v. 1972 (Y. Hirashima) ;6 꾸 15. iv. 1984 (Y. Abe). 
Table 1. Degree of melanism of hairs in the female of Andrena (Andrena) mikado. Code numbers are shown in Fig. 2.

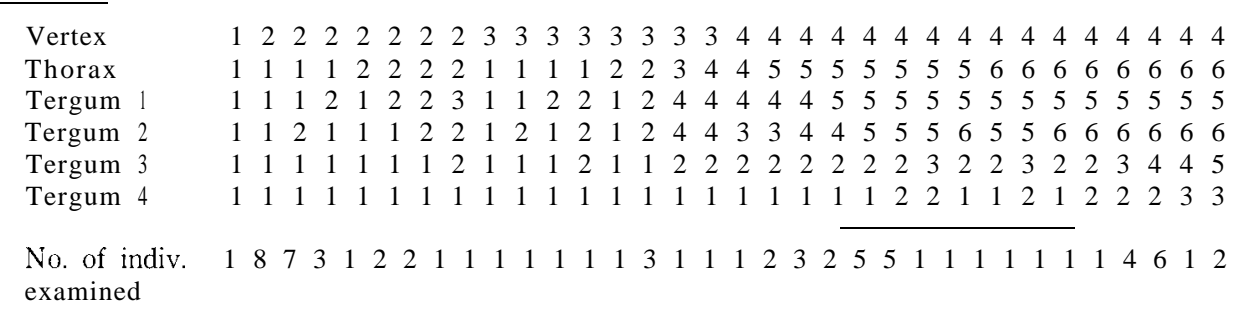

Table 2. Distribution of various populations of Andrena (Andrena) mikado concerned with melanism of hairs on the metasomal terga 1-4. Code numbers are shown in Fig 2

\begin{tabular}{|c|c|c|c|c|c|c|c|c|c|c|c|c|c|c|c|c|c|c|c|c|c|c|}
\hline \multirow{5}{*}{ Population } & \multicolumn{19}{|c|}{ Degree of melanism of hairs } & \multirow[b]{2}{*}{5} & \multirow[b]{2}{*}{5} & \multirow{5}{*}{$\stackrel{\pi}{0}$} \\
\hline & MT1 & 1 & 1 & 2 & 2 & 2 & 3 & 4 & 4 & 5 & 5 & & 5 & 5 & 5 & 5 & 5 & 5 & 5 & & & \\
\hline & MT2 & 1 & 2 & 1 & 2 & 2 & 2 & 3 & 4 & 4 & 5 & 5 & 5 & 5 & 5 & 6 & 6 & 6 & 6 & 6 & 6 & \\
\hline & MT3 & 1 & 1 & 1 & 1 & 2 & 2 & 2 & 2 & 2 & 2 & 2 & 2 & 3 & 5 & 2 & 2 & 3 & 4 & 4 & 5 & \\
\hline & MT4 & 1 & 1 & 1 & 1 & 1 & 1 & 1 & 1 & 1 & 1 & & 2 & 2 & 2 & 1 & 2 & 2 & 2 & 3 & 3 & \\
\hline Miyagi & & & & 1 & & & & & & & & & & & & & & & & & & 1 \\
\hline Tochigi & & & 1 & & & & & & 1 & & & & & & & & & & & & & 2 \\
\hline Saitama & & & & & & & & 1 & & & & & & & & & & & & & & 1 \\
\hline Kanagawa & & & & & & & & & & & & & 1 & & & & & & & & & 1 \\
\hline Mie & & & & & & & 1 & & & & 1 & & & & & & & & & & & 2 \\
\hline Shiga & & & & & & & & 1 & & & & & & & & & & & & & & 1 \\
\hline Kyoto & & & & & & & & & & & & & 1 & & 1 & & & & & & & 2 \\
\hline Hyogo & & & & & & & & & & & & & & & & & & 1 & & & & 1 \\
\hline Tottori & & & & & & & & & 1 & & & & & & & & & & & & & 1 \\
\hline Shimane & & 1 & & 1 & 4 & & & 1 & 1 & 2 & 4 & & 1 & 1 & & 2 & & 111 & 6 & & 1 & 37 \\
\hline Hiroshima & & 2 & 1 & 1 & & & & & 1 & & 1 & & 1 & & & & & 1 & & & & 8 \\
\hline Ehime & & & & & & & & & & & & & & & & & & 1 & & & 1 & 2 \\
\hline Fukuoka & & 1 & & & & & & & & & & & & & & & & & & 1 & & 2 \\
\hline Oita & & 10 & & 1 & & & & & & & & & & & & & & & & & & 11 \\
\hline Kumamoto & & 15 & & & & 1 & & & & & & & & & & & & & & & & 16 \\
\hline Kagoshima & & 1 & 1 & & & & & & & & & & & & & & & & & & & 2 \\
\hline Yakushima Is. & & & & & & & & & 1 & & & & & 1 & & & & & & & & 2 \\
\hline Total & & 30 & 3 & 4 & 4 & 1 & 1 & 3 & 5 & 2 & 6 & 4 & 2 & 1 & 2 & 1 & 1 & 4 & 6 & 2 & 9 & 2 \\
\hline
\end{tabular}

Other localities (*new records) :Towada (Aomori Pref.) ; Mt. Zao (Miyagi Pref.) ; Nasu-Yumoto (Tochigi Pref.) ; Mt. Bukka (Kanagawa Pref.) ; *Shosenkyo (Yamanashi Pref.) ; Mt. Gozu (Niigata Pref.) ; Fukui, Eiheiji, Katsuyama, Ohno, Izumi, Sabae, Takefu, Imajo, Nanjo, Tsuruga, Mikata (Fukui Pref.) ; Yamanaka (Shiga Pref.); *Kyoto (Kyoto Pref.); *Takedao, ${ }^{*}$ Sasayama, Rokko (Hyogo Pref.); ${ }^{*}$ Kumayama, ${ }^{*}$ Okutsu (Okayama Pref.) ;*Yoshiwa, ${ }^{*}$ Fukuoji, Mt. Abusan, Yahatamura (Hiroshima Pref.) ; ${ }^{*}$ Matsue-Inbe, ${ }^{*}$ Hikimi (Shimane Pref.); Omogo (Ehime Pref.) ; Mt. Sangun (type locality, Fukuoka Pref.) ; Yakushima Is. 
4. Andrena (Andrena) ishiharai Hirashima

(Figs. 3, 18, 33a and b, 94, Table 4)

Andrena (Andrena) ishiharai Hirashima, 1953, Trans. Shikoku Ent. Soc., $3: 33$, female ; Hirashima, 1962, J. Fac. Agr., Kyushu Univ., 12 : 132, female \& male ; Hirashima, 1966, ibid., 14 : 101 and 116.

This species has two generations a year. There are some differences in characters between the spring and summer specimens in male.

First generation : Clypeus tessellate nearly all over ; flagellar segment 1 as long as wide, much shorter than 2 (Fig. 33a) ; mesoscutum densely tessellate with indistinct punctures; metasomal terga tessellate with indistinct punctures ; hairs on clypeus long, black mixed with fulvous ones.

Second generation : Clypeus tessellate only basally, smooth and shiny apically; flagellar segment 1 one and half times as long as wide, about as long as 2 (Fig. 33b) ; mesoscutum less tessellate with more distinct punctures ; metasomal terga weakly tessellate with distinct punctures ; hairs on clypeus shorter, black.

Distribution : Japan (Hokkaido, Honshu, and Shikoku). (Fig. 49)

Floral records : Ikudome (1983) recorded D. crenata Sieb. et Zucc. We record 14 plants as follows : First generation : Compositae :Taraxacum officinale Weber (2 f 9 $\sigma^{7) ;}$ Petasites japonicus subsp. giganteus Kitam.(4). Salicaceae : Salix Hultenii var. angustifolia Kimura (8우); S.taraikensis Kimura (23우); S. sp. (1 $\left.\sigma^{7}\right)$. Cruciferae : Brassica Napus L. (2 $\left.\sigma^{7}\right)$. Caprifoliaceae : Weigela hortensis Koch. (1 우). Second g. : Ranunculaceae :Cimicifuga simplex Wormsk. (2 우 16). Umbelliferae : Angelica ursina Maxim. (7 우12 $\sigma^{7}$ ). Araliaceae : A valia cordata Thunb. (3 $\sigma^{7)}$; A. elata Seemann (1 우). Compositae :Solidago Virga-aurea L. (1 우); Aster glehnii var. hondoensis Kitam. (1 우). Polygonaceae : Polygonum sachalinense Fr. Schmidt (1 $\left.\sigma^{7}\right)$.

Flight records : Two generations a year. Female: 1st generation: mid May (Shikoku) ; late May to early June (Honshu) ; late May to mid June (Hokkaido). 2nd g. : late August to mid September (Honshu) ; mid August to mid September (Hokkaido). Male : 1st g. : early to late May (Honshu) ; early May to early June (Hokkaido). 2nd g. : early July to early September (Honshu); mid to late August (Hokkaido).

Specimens examined : We have examined 33 females and 24 males of the 1 st generation and 18 females and 50 males of the 2nd. Some of them are cited as follows : HOKKAIDO : Kussharo-ko, Teshikaga :7 $\sigma^{7}, 26$. v. 1984 (0. Tadauchi) ;1 $\sigma^{\pi}, 30$. viii. 1984 (0. Tadauchi) ; 2 우, 12. ix. 1984 (0. Tadauchi) ; Shotoshibetsu, Rikubetsu : 46, 7. v. 1984 (0. Tadauchi) ; 7 우, 27. v. 1984 (0. Tadauchi) ; 1 우, 13. vi. 1984 (0. Tadauchi) ; 23 우, Tokachimitsumata, Kamishihoro, 29. v. 1984 (0. Tadauchi) ;1우, Shikaribetsuko, Kamishihoro, 24. v. 1984 (0. Tadauchi) ; Kogen Spa, Mt. Taisetsu :2 우9 $0^{7}, 13$. viii. 1984 (0. Tadauchi) ;5 우 $4 \sigma^{7}, 15$. viii. 1984 (0. Tadauchi) ; 1 우, Yamabe, Furano, 23. v. 1984 (0. Tadauchi) ; $10^{7}$, Hokkaido Univ. Campus, Sapporo, 13. v. 1984 (0. Tadauchi). HONSHU :1우, Mt. Yudono, Yamagata Pref., 9. vi. 1977 (K. Baba) ; 1 ๖, Karisaka, Saitama Pref., 2. viii. 1973 (T. Nanbu) ;1 , Kamikochi, Nagano Pref., 28. viii. -3. ix.

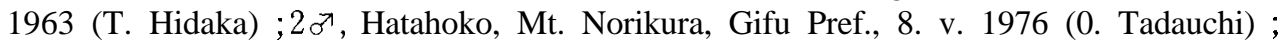
1 우, Arashi, Ohno, Fukui Pref., 30. viii. 1974 (Y. Haneda) ; 16, Kurami, Kamo, Okayama Pref., 3. v. 1967 (S. Takeuchi).

Other localities (*new records) : Hamakoshimizu, Kitamoshiri, Ashoro, *Asa- 


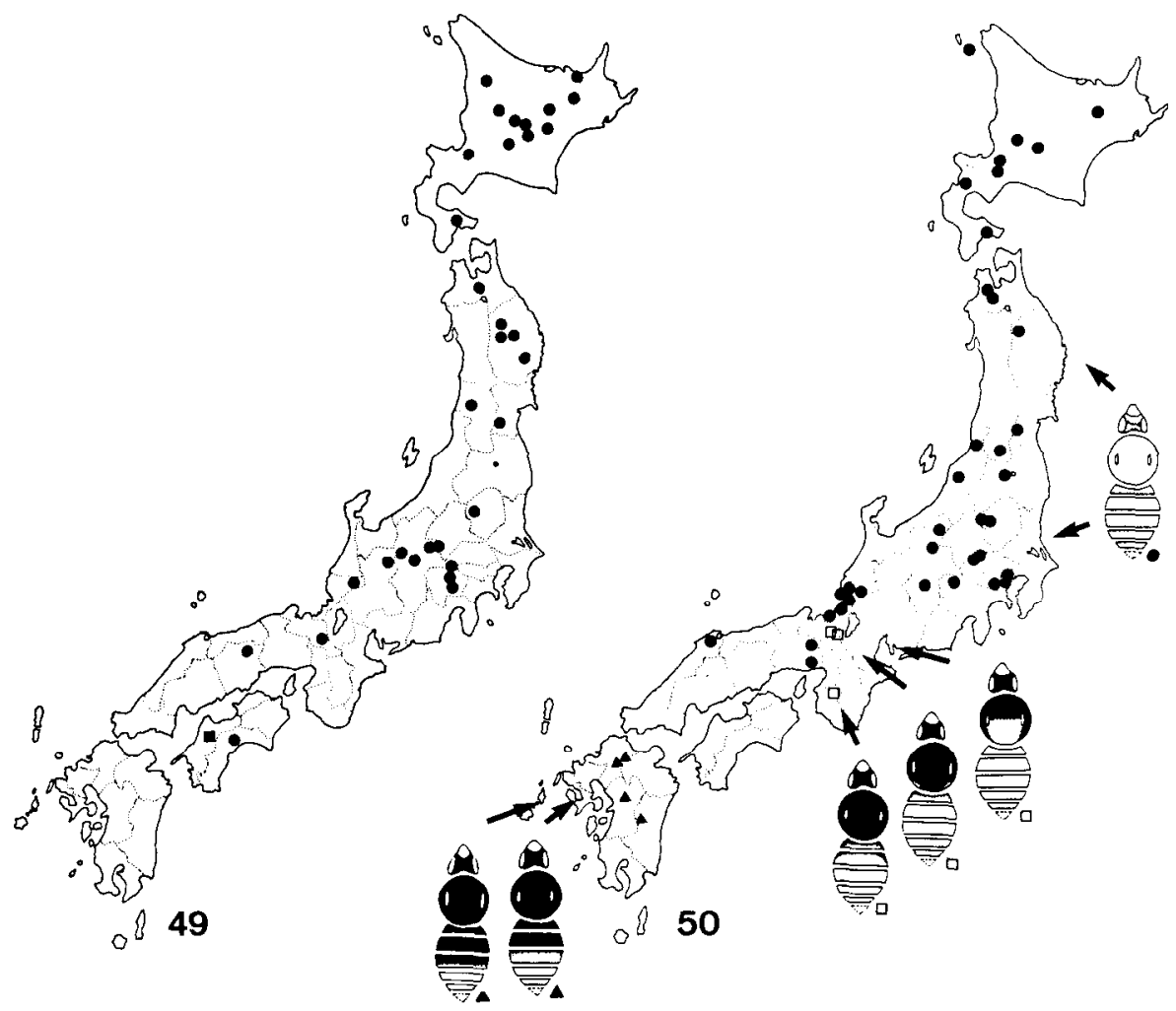

Figs. 49-50. Maps showing the distributions of Andrena (Andrena) ishiharai Hirashima (49) and A. (A.) nawai Cockerell (50). A black square indicates the type locality.

hikawa, Narukawa (Hokkaido) ; Towada (Aomori Pref.) ; *Mt. Himekami, *Ashiro, *Sennin-toge, *Mt. Sode (Iwate Pref.); Mt. Zao (Miyagi Pref.); NikkoYumoto (Tochigi Pref.); *Mt. Fuji, *Hajikano (Yamanashi Pref.) ; ${ }^{*}$ Karuizawa, Usui-toge, ${ }^{*}$ Utsukushigahara (Nagano Pref.) ; Katsuyama, Ohno, Obama (Fukui Pref.) ; Omogo (type locality, Ehime Pref.) ; Tosayama (Kochi Pref.).

\section{Andrena (Andrena) nawai Cockerell}

(Figs. 4, 19, 34, 50-57, 94, Tables 3, 4)

Anthrena juponica Alfken, 1900, Ent. Nachr., $26: 178$, female.

Andrena simulans Perez, 1905, Bull. Mus. d'Hist. Nat. Paris, 1905 : 34, male ; Cockerell, 1913, Ann.

Mag. nat. Hist., (8) $11: 189$, male.

Andrena nawai Cockerell, 1913, Ann. Mag. nat. Hist., (8) 11 : 188, female ; Yasumatsu, 1941, Peking Nat. Hist. Bull., 15 : 279.

Andrena simulatilis Viereck, 1918, Proc. biol. Soc. Washington, 31 : 59.

Andrena nipponicu Cockerell, 1922, Proc. U. S. Nat. Mus., $60: 11$; Yasumatsu, 1941, Peking Nat. Hist Bull., 15 : 279. 


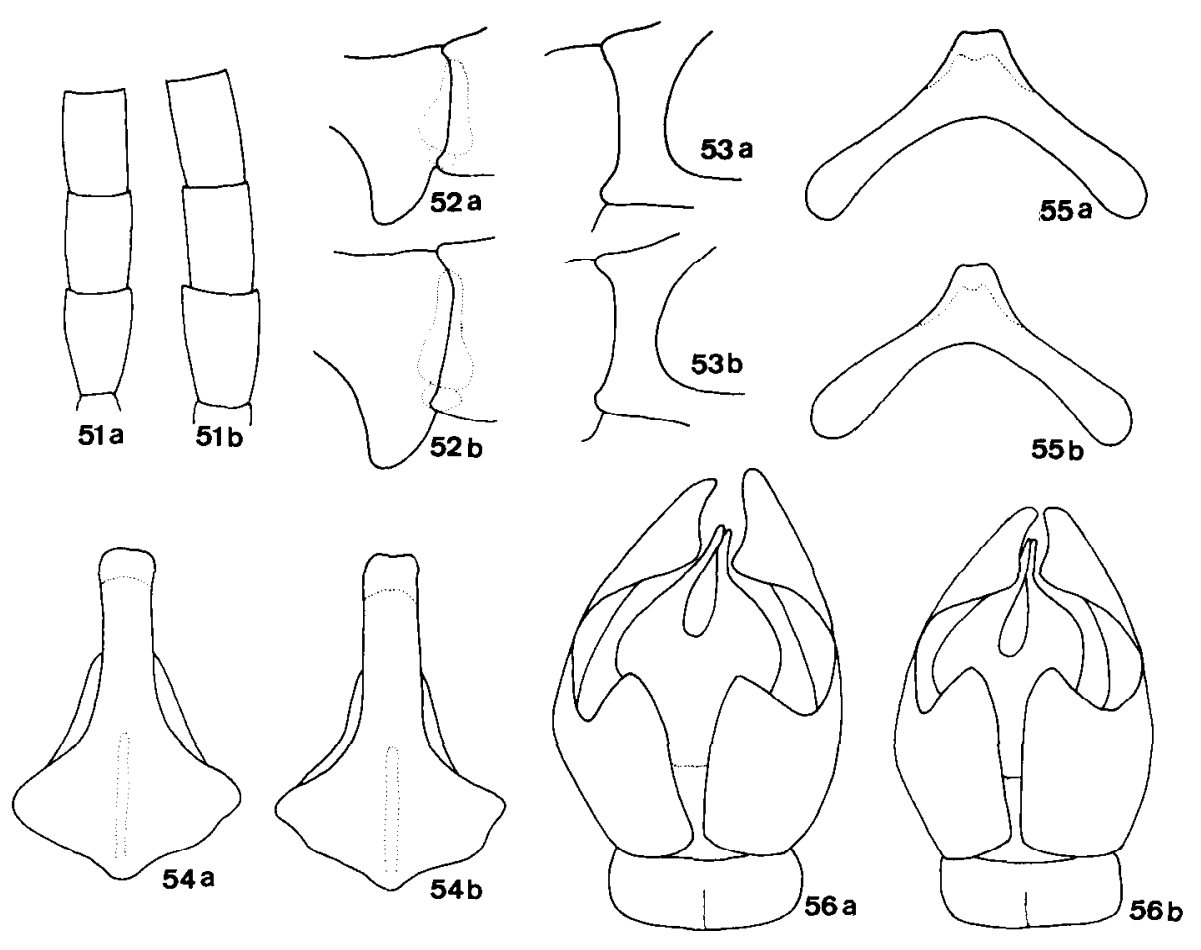

Figs. 51-56. Comparison of various morphological characters in the males of nawai collected from two localities, a: Kussharo-ko, Hokkaido, b: Mt. Hikosan, Kyushu, $51: 1$ st to 3 rd flagellar segments, 52 : ventral projections of mandibles, 53 : malar spaces, $54: 7$ th sterna, $55: 8$ th sterna, $56:$ genital capsules.

Andrena japonica Alfken, 1924, Konowia, 3 : 95, male.

Andrena (Melandrena) mikado Strand et Yasumatsu, 1938, male.

Andrena (Andrena) bombiformis Yasumatsu et Hirashima, 1962, J. Fac. Agr., Kyushu Univ., 12 : 130 , female; Hirashima, 1966, ibid., $14: 101$, n. syn.

Andrena (Andrena) nawai Hirashima, 1962, J. Fac. Agr., Kyushu Univ., 12 : 133, female \& male ; Hirashima, 1966, ibid., $14: 102 \& 116$.

Yasumatsu and Hirashima (1962) pointed out that Andrena (A.) bombiformis is structurally very close to Andrena nawai Cockerell except for the color of female pubescence. In the present study we examined the newly collected males from Mt. Hikosan, Kyushu, where the females of bombiformis have been collected, but not the so-called nawai Figures 51-56 show the 1st to 3rd flagellar segments, the projection of the mandible, the malar space, the 7th and 8th sterna, and the genital capsule each for the two male specimens from Kyushu (bombiformis) and Hokkaido (nawai). From the examination we could not find any differences in the males from the two areas. As to the females we could find various intermediate forms between nawai and a typical bombiformis as shown in Fig. 57. As shown in Andrena (Andrena) mikado, nawai coded as 11111 is connected with a typical bombiformis coded as 24453 by some 
intermediate forms. Table 3 and Fig. 57 show the variation of the pubescence color and its distribution. A typical nawai has been collected from Hokkaido to Chugoku Districts, Honshu, and the intermediate forms have been taken from Kinki Districts. On the other hand, bombiformis collected in Kyushu shows a variation from 24432 to 24453. Taking the above examination into consideration, we recognize that bombiform-

A

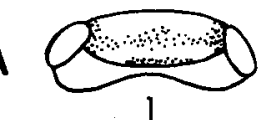

B

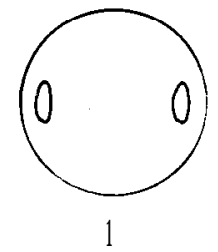

C

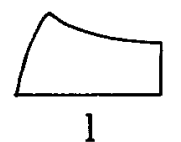

D

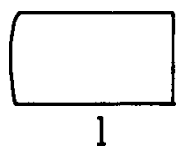

E
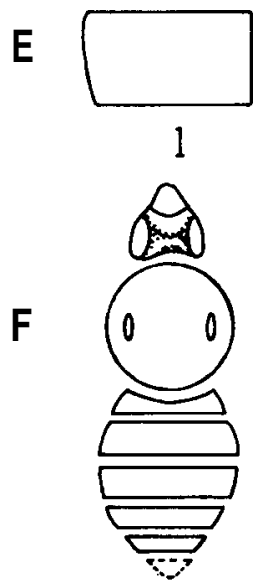
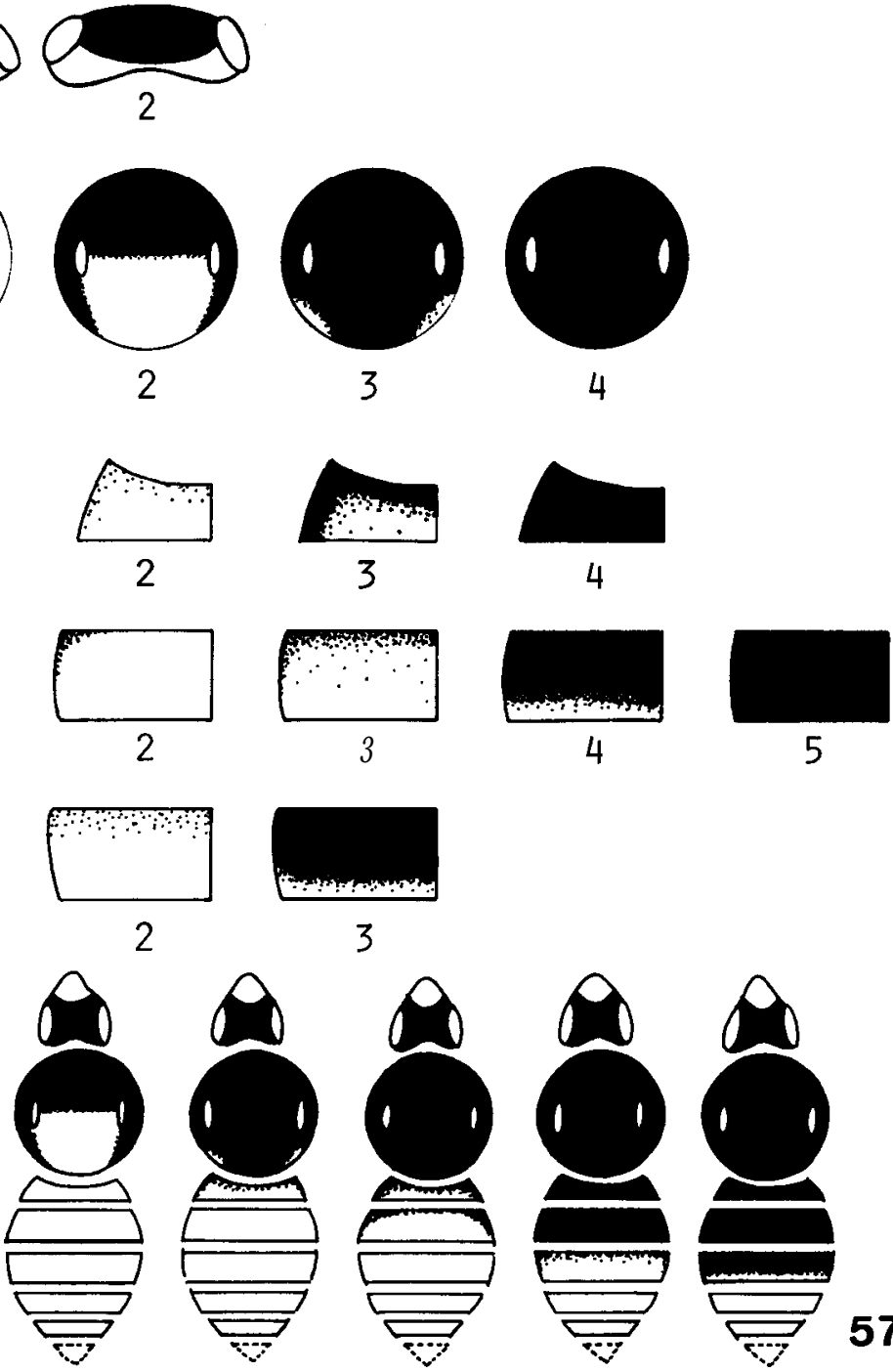

57

Fig. 57. Variation of color of the hairs in the female of Andrena (Andrena) nawai, A: vertex, B: thorax including propodeum, C: 1st metasomal tergum, D: 2nd metasomal tergum, $\mathrm{E}: 3 \mathrm{rd}$ metasomal tergum, $\mathrm{F}:$ some representative types in color of hairs. 
Table 3. Distribution of various populations of Andrena(Andrena) nawai concerned with melanism of hairs on the female head, thorax, and metasomal terga 13 . Code numbers are shnwn in Fig. 5.

\begin{tabular}{|c|c|c|c|c|c|c|c|c|c|}
\hline \multirow{5}{*}{ Population } & \multicolumn{9}{|c|}{ Degree of melanism of hairs } \\
\hline & Head & 1 & 2 & 2 & 2 & 2 & 2 & 2 & \multirow{4}{*}{ 중 } \\
\hline & $\begin{array}{l}\text { Thorax } \\
\text { MT1 }\end{array}$ & 1 & 2 & $\begin{array}{l}3 \\
2\end{array}$ & $\begin{array}{l}4 \\
3\end{array}$ & $\begin{array}{l}4 \\
4\end{array}$ & $\begin{array}{l}4 \\
4\end{array}$ & 4 & \\
\hline & MT2 & 1 & 1 & 1 & 2 & 3 & 4 & 5 & \\
\hline & MT3 & 1 & 1 & 1 & 1 & 2 & 3 & 3 & \\
\hline Hokkaido & & 34 & & & & & & & 34 \\
\hline Aomori, Miyagi & & 2 & & & & & & & 2 \\
\hline Tochigi, Tokyo & & 2 & & & & & & & 2 \\
\hline Yamanashi, Nagano & & 2 & & & & & & & 2 \\
\hline Kyoto & & & 1 & 1 & & & & & 2 \\
\hline Wakayama & & & & & 1 & & & & I \\
\hline Hyogo & & 2 & & & & & & & 2 \\
\hline Shimane & & 12 & & & & & & & 12 \\
\hline Fukuoka & & & & & & 1 & 3 & 1 & 5 \\
\hline Total & & 54 & 1 & 1 & 1 & 1 & 3 & 1 & 62 \\
\hline
\end{tabular}

is is a black form of nawai as shown in Andrena (Andrena) mikado.

Distribution : Japan (Hokkaido, Rishiri Is., Honshu and Kyushu). (Fig. 50)

Floral records : Miyamoto (1960) recorded 9 plants belonging to 6 families for nawai and Yasumatsu and Hirashima (1962) recorded Rubus sp. for bombiformis. We have examined 46 females and 41 males taken on 10 plants as follows : Compositae : Petasites japonicus subsp. giganteus Kitam. (8 우29 $\left.\sigma^{7}\right)$; Taraxacum officinale Weber (3 우 66). Salicaceae : Salix rorida Lackschewitz (12우 2 ); S. koriyanagi Kimura (1 $\left.\sigma^{7}\right)$; $S$. sp. (5우 $2 \sigma^{7}$ ). Rosaceae: Prunus Sargentii Rehd. (13우); P. jamasakura Sieb. (1 우); $P$. Mume Sieb. et Zucc. (1 우); Chaenomeles japonica Lindl. (2우). Cruciferae :Brassica pekinensis Pupr. (1우 16).

Flight records : Female : early April to mid May (Kyushu); late March to late May (Honshu) ; mid April to mid June (Hokkaido). Male: late March to late April (Kyushu); late March to late May (Honshu); early April to mid May (Hokkaido).

Specimens examined : We have examined 75 females (67 yellow forms and 8 black and intermediate forms) and 84 males. Female (yellow form) and male: HOKKAIDO : 15 우29 잉. Kussharo-ko, Teshikaga, 6. v. 1984 (0. Tadauchi) ;2오, same locality and collector as above, 26. v. $1984 ; 10$ 우, Ashibetsu-ko, Ashibetsu, 22. v. 1984 (0. Tadauchi); $1 \Im^{\top}$, Yamabe, Furano, 11. v. 1984 (0. Tadauchi); 2 오 $2 \varsigma^{\Im}$, Hokkaido Univ. Campus, Sapporo, 13. v. 1984 (0. Tadauchi) ; 2 ㅇ, Yamada Spa, Niseko, 20. v. 1984 (0. Tadauchi). HONSHU :1万7, Mt. Bonju, Aomori Pref., 24. iv. 1960 (Y. Murakami) ; 1 ㅇ 46, Chuzenji, Nikko, Tochigi Pref., 11. v. 1976 (0. Tadauchi); 36, Mt. Jomine, Saitama Pref., 14. iv. 1973 (T. Nanbu) ; 26, Masutomi, Kanayama, Yamanashi Pref., 5. iv. 1962 (T. Saigusa) ;1 ơ , Nakagawa, Yamanashi Pref., 9. iv. 1962 (T. Saigusa) ;2 $\sigma^{7}$, Mt. Makunagi, Matsue, Shimane Pref., 22. iii. 1982 (Y. Ohno);2우, Nagae, Matsue, Shimane Pref., 30. iii. 1982 (Y. Maeta);7우, Nishikawatsu, Matsue, Shimane Pref., 1. iv. 1985 (N. Kubota \& N. Sugiura); 16, Hikimi, Shimane Pref., 6. iv. 1986 ( 0 . 
Tadauchi). KYUSHU : Mt. Hikosan, Fukuoka Pref. : $1 \sigma^{7}, 19$. iv. 1938 (K. Yasumatsu); $1 \sigma^{7}, 28$. iv. 1975 (K. Ôhara);1ð, Kugino, Aso, Kumamoto Pref., 28. iii. 1960 (Y. Miyatake). Female (intermediate form) : HONSHU : 1 우, Kibune, Kyoto, 14. iv. 1935 (Takeuchi) ; 1 우, Mt. Hiei, Kyoto Pref. ;1오, Mt. Koya, Wakayama Pref., 27. iv. 1976 (0. Tadauchi). Female (black form) : KYUSHU : 1 우, Mt. Shakadake, Yame, Fukuoka Pref., 15. iv. 1962 (S. Ide) ; 1 오, Mt. Hikosan, Fukuoka Pref., 25. iv. 1975 (K. Takeno)

Other localities (*new records) : Rishiri Is., * Jozankei, Narukawa, Hakodate (Hokkaido) ; *Kuroishi (Aomori Pref.) ; *Ashiro (Iwate Pref.) ; Mt. Zao (Miyagi Pref.) ; Yonezawa (Yamagata Pref.) ;*Aizu-wakamatsu (Fukushima Pref.) ; NikkoYumoto (Tochigi Pref.) ; *Kodama (Saitama Pref.) ; *Meguro, Toyotama (Tokyo) ; *Jokoji (Yamanashi Pref.) ; ${ }^{*}$ Ueda, *Shiga-kogen, *Kamikawa-mura, Ina (Nagano Pref.); Kurokawa, Niitsu (Niigata Pref.); *Funaokayama (Ishikawa Pref.) ; Fukui, Ohno, Shimizu, Echizen, Sabae, Takefu, Mihama, Takahama (Fukui Pref.) ; Sasayama, Rokko (Hyogo Pref.) ; *Mt. Aso (Kumamoto Pref.) ; Shiiba-mura (Miyazaki Pref.).

\section{Andrena (Andrena) esakii Hirashima}

(Figs. 5, 20, 35, 58, 94, Table 4)

Andrena (Andrena) esakii Hirashima, 1957, Mushi, 30 : 49, female ; Hirashima, 1962, J. Fac. Agr., Kyushu Univ., 12 : 137, female \& male ; Hirashima, 1966, ibid., 14: 102 and 116.

Distribution : Japan (central Honshu, Shikoku and Kyushu). (Fig. 58)

Floral record : Two females and 4 males have been collected on Acer sp. (Aceraceae).

Flight records : Female : early April to late May (Kyushu). Male : mid April to early May (Kyushu) ; late April (Shikoku) ; early June (Honshu).

Specimens examined : HONSHU :1ळ, Mt. Heko, Ikeda, Fukui Pref., 6. vi. 1981 (H. Kurokawa). KYUSHU : Mt. Hikosan. Fukuoka Pref. :1 $1 \sigma^{\pi}$, 3. v. 1962 (M. T. Chûjô); 16, 18. iv. 1972 (K. Takeno); 16, 28. iv. 1972 (M. T. Chûjô̂);1우, 28. v. 1972

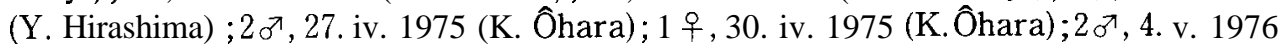
(K. Ôhara).

Other localities :Ohno, Izumi, Imajo (Fukui Pref.) ; Omogo (Ehime Pref.).

\section{Andrena (Andrena) saragamineensis Hirashima (Figs. 6, 21, 36, 59, 94)}

Andrena (Andrena) saragamineensis Hirashima, 1962, J. Fac. Agr., Kyushu Univ., 12 : 149, female \& male ; Hirashima, 1966, ibid., $14: 104$ and 115.

Distribution : Japan (central Honshu and Shikoku). (Fig. 59)

Floral record : Not available.

Flight records : Female : mid April (Shikoku) ; early April to early May (Honshu). Male : mid April (Shikoku); early April to early May (Honshu).

Specimens examined : HONSHU : 1 우, Shimizu, Ohno, Fukui Pref., 30. iv. 1965 (Y. Haneda) ;1 $\sigma^{7}$, Oyato, Ohno, Fukui Pref., 29. iv. 1980 (Y. Haneda) ;1 우, Tenjin, Fukui, Fukui Pref., 25. iv. 1965 (Y. Haneda) ;1우, Awaka, Fukui, Fukui Pref., 8. iv. 1981 (Y. Haneda). 


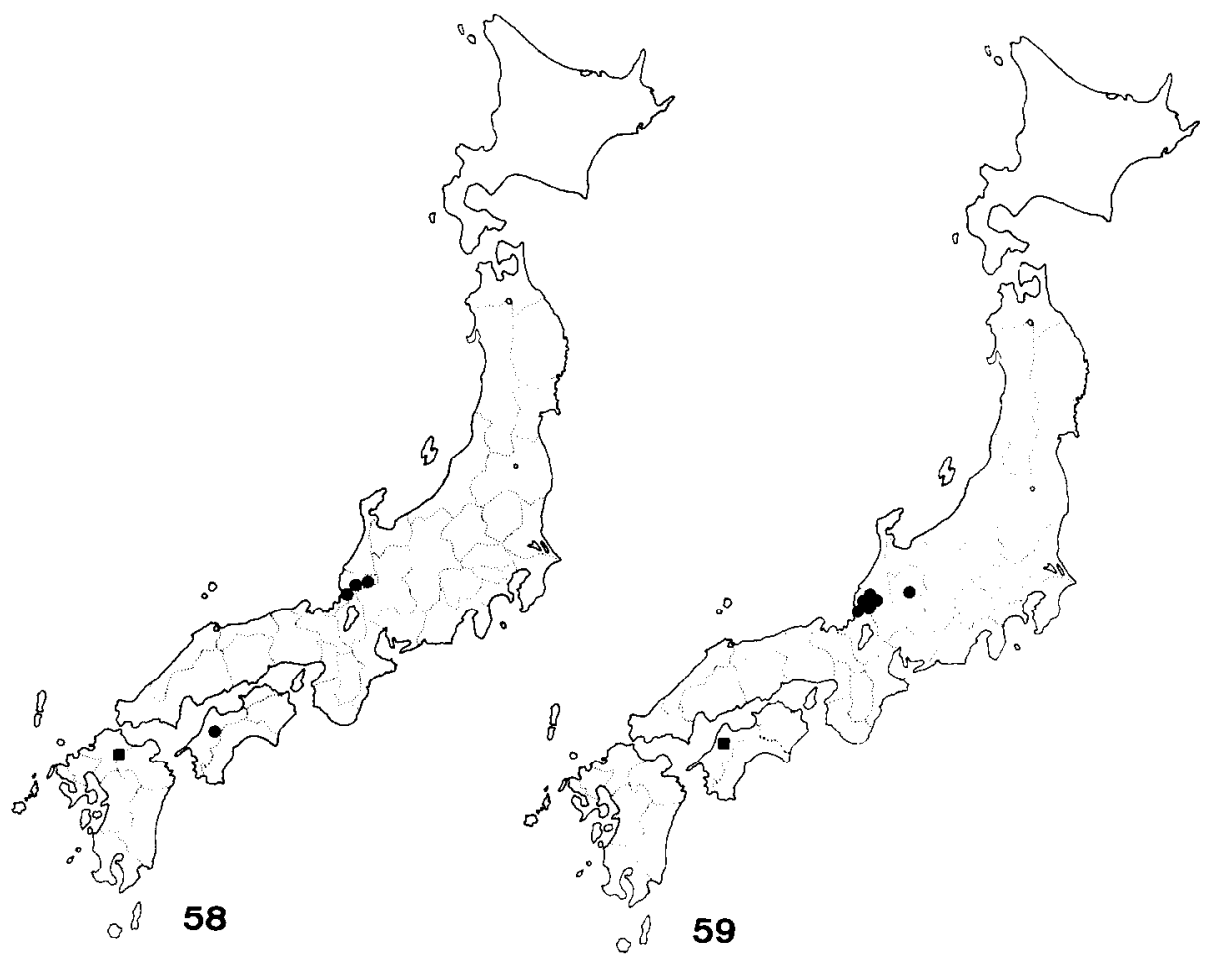

Figs. 58-59. Maps showing the distributions of Andrena (Andrew) esakii Hirashima (58) and A. (A.) saragamineensis Hirashima (59). A square indicates the type locality.

Other localities : Katsuyama, Ikeda, Shimizu, Sabae, Takefu (Fukui Pref.) ; Osaka (Gifu Pref.) ; Mt. Saragamine (type locality Ehime Pref.).

8. Andrena (Andrena) sakagamii, Tadauchi, Hirashima et Matsumura, new species (Figs. 7, 22, 37, 60-65, 94, Table 4)

Andrena (Andrena) sp. 1, Tadauchi \& Hirashima, 1986, Trans. Essa Ent. Soc., (63) : 17.

This new species is close to Andrena (A.) benefica Hirashima. But, it is separable from benefica by the following characters : mesoscutum more roughened with closer punctures (sparsely and indistinctly punctate in benefica), clypeus slightly tessellate and sparsely punctate apically (broadly smooth and shiny apically in benejica), facial fovea narrow (narrower than in benejica), and caudal fimbria golden (pale brownish in benefica). This species is somewhat similar to the European Andrenahelvola (Linnaeus). But it is separated from helvola by the smaller size, scanty hairs on metasoma, densely and rugosely punctate mesoscutum, and paler caudal fimbria.

So far as the present study is concerned, this species occurrs in Hokkaido and northern Honshu (Iwate, Niigata and Tochigi Prefs.). It is found primarily on the flowers of Taraxacum officinale Weber. 

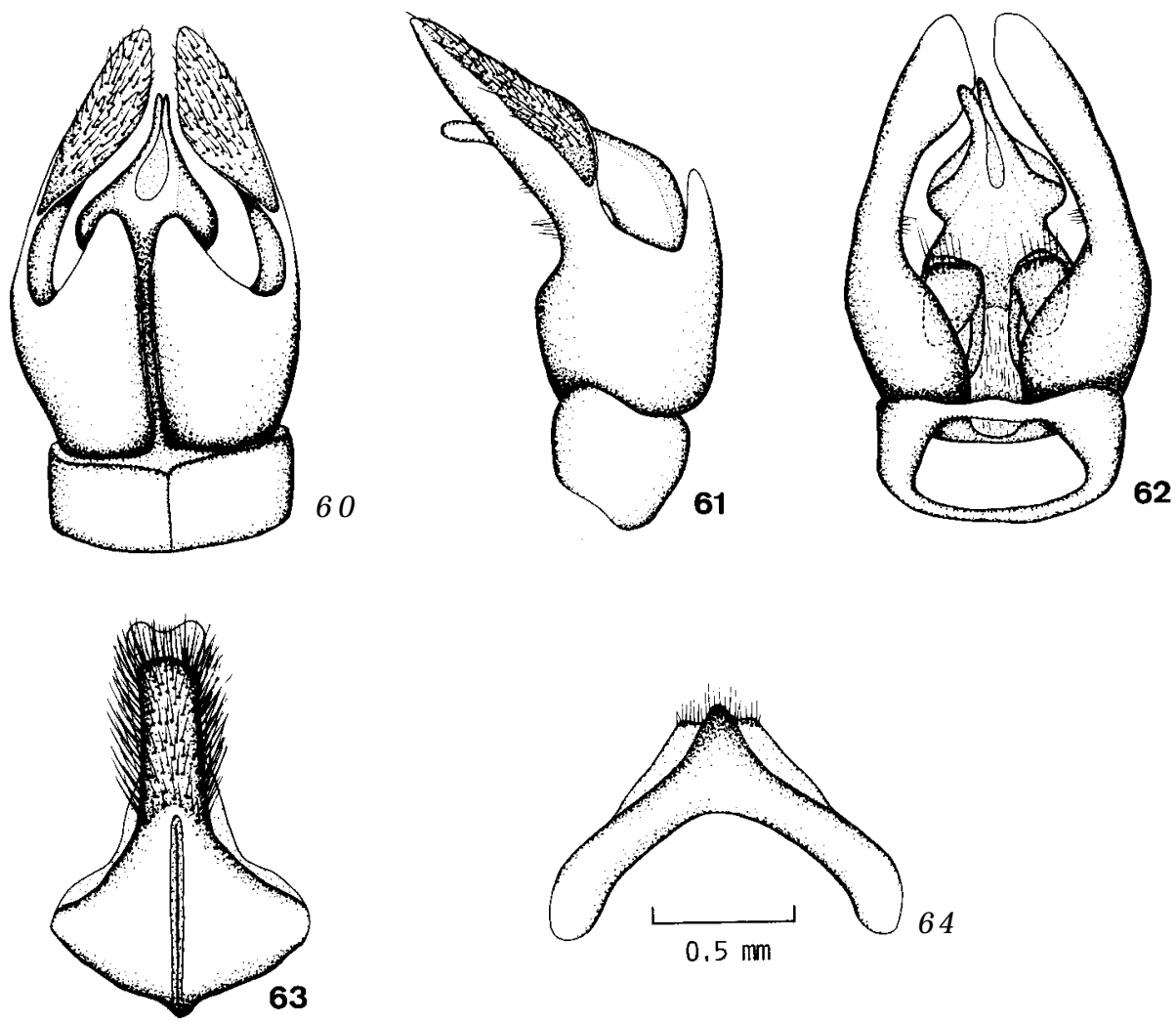

Figs. 60-64. Genital capsule and associated structures of Andrena (Andrena) sakagamii, new species, $60:$ dorsal view of genital capsule, $61:$ lateral view of the same, 62 : ventral view of the same, $63: 7$ th sternum, $64: 8$ th sternum.

Female : Length $8.5-9.5 \mathrm{~mm}$.

Integumental color : Flagellum brown beneath; hind tibia and tarsus brown to reddish brown; posterior margins of metasomal terga reddish brown subhyaline.

Pubescence : Hairs on head and thorax short, not dense, those on head whitish, those on paraocular and genal areas near eye and vertex brownish ; facial fovea chocolate above, paler below ; facial fovea with upper end occupying $3 / 4$ space between eye and post ocellus (nearly full space in benefica); hairs on thorax whitish to fulvous above, whitish below ; tibial scopa white, slightly brownish above, composed of well arranged hairs, which are longer than those in benejica; hairs on metasomal terga scanty, white ; caudal fimbria golden (yellowish brown in benejica) ; posterior margins of metasomal terga 2-4 each with an apical, obscure fringe of white hairs.

Structure : Process of labrum transverse ; malar space about $1 / 4$ times as long as base of mandible ; clypeus well convex, with basal half tessellate and apical half slightly tessellate, sparsely punctate with punctures irregular in size and distribution ; clypeus with a median, impunctate space distinct even on apical area (apical portion 


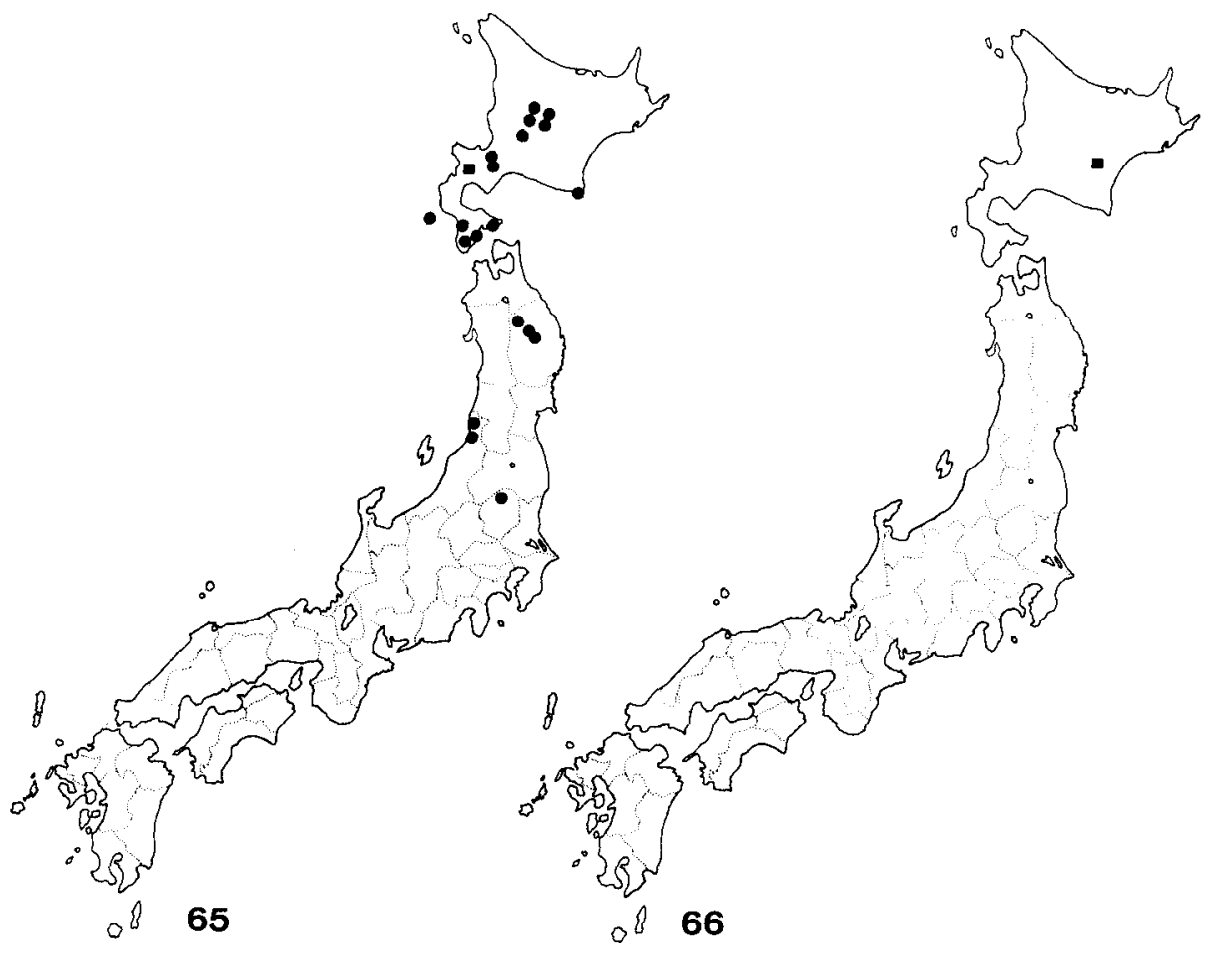

Figs. 65-66. Maps showing the distributions of Andrena (Andrena) sakagamii, new species (65) and $A$. (A.) apicata aino, new subspecies (66). A square indicates the type locality.

of clypeus broadly impunctate in benefica); mesoscutum and mesoscutellum weakly tessellate and weakly shiny with a little roughened, very close punctures (densely tessellate with sparse punctures in benefica); propodeum roughened, dull, enclosure ill defined, weakly rugose basally, densely tessellate apically ; mesepisternum shagreened anteriorly, densely tessellate posteriorly with weak, indistinct punctures ; metasomal terga densely tessellate, nearly impunctate ; posterior depressions of terga broad, not well indicated.

Male : Length 8.0-9.0 mm.

Integumental color : mandibles reddened apically ; flagellum brownish beneath ; posterior margin of metasomal terga reddish brown subhyaline.

Pubescence : Hairs on head pale yellowish to fulvous ; those on clypeus relatively dense, long; those on paraocular area, frons and genal area near eye and vertex mixed with sparse, brownish hairs; those on thorax pale yellowish to fulvous above, paler below ; those on legs pale yellowish ; those on metasomal tergum 1 long, pale yellowish, terga 2-5 short, tergum 6 golden; metasomal sterna 2-5 each with a long, curled fringe of fulvous hairs apically.

Structure : Mandible long, curved, without a basal projection ; malar space very narrow, about $1 / 6$ times as long as base of mandible ; process of labrum small, smooth 
and shiny ; clypeus nearly flat, tessellate on basal $1 / 6$, and shiny and smooth apically with distinct punctures all over ; genal area distinctly angled behind ; flagellum 1 one and half times as long as wide, longer than 2, and slightly longer than 3 ; mesoscutum weakly tessellate with sparse, shallow punctures ; mesoscutellum very weakly tessellate, sparsely punctate anteriorly and densely punctate posteriorly ; propodeum shagreened, enclosure ill defined, rugose on basal $1 / 4$, tessellate apically ; mesepisternum shagreened with shallow punctures ; metasomal terga weakly tessellate, becoming smoother toward apical terga; posterior depressions of terga broad, indistinct, genitalia and associated structures as illustrated (Figs. 60-64).

Distribution : Japan (Hokkaido, Okushiri Is., and northern Honshu). (Fig. 65)

Floral records : Eighty-eight females have been collected on 10 plants. Taraxacum officinale is predominant $(72.7 \%)$. Compositae : Taraxacum officinale Weber (64 우); Bellis perennis L. (2 우). Rosaceae : Prunus Sargentii Rehd. (2 우). Salicaceae : Salix sp. (5 우). Liliaceae : Erythronium japonicum Decne. (9 우). Ericaceae : Rhododendron sp. (2 우). Caprifoliaceae : Weigela hortensis Koch. (1 우). Araliaceae : Aralia elata Seemann (1 우). Staphyleaceae : Staphylea bumalda DC. (1우). Violaceae : Viola verecunda A. Gray (1 우).

Flight records : Female : early April to mid June (Honshu) ; late April to mid June (Hokkaido). Male : early May (Hokkaido).

Type material : Holotype female (Type No. 2572, Kyushu Univ.), Yamada Spa, Niseko, Hokkaido, 20. v. 1984 (0. Tadauchi). Paratypes : HOKKAIDO : 14 우, Erimo, 31. v. 1975 (0. Tadauchi) ; 13 우, Asahiyama, Asahikawa, 13. v. 1969 ; 2 우, same locality as above, 11. vi. 1969 ; 2 우, Nokanan, 8. vi. 1967 ; 1 우, Inosawa, Asahikawa, 7. v. 1970 ; 1 우, same locality as above, 10. v. $1969 ; 1$ 우, Yukomanbetsu, 16. v. $1967 ; 1$ 우, Ashibetsu-ko, Ashibetsu, 22. v. 1984 (0. Tadauchi) ;2 , Botanical Garden, Sapporo, 7. v. 1959 (S. F. Sakagami) ; 1 우, Moiwa, Sapporo, 11. v. 1972 (Kawano) ;1우, same data as holotype ;2 우, Esashi, 14. v. 1966 (M. Munakata) ; 4 우, Shirikishinai, Oshima, 28. iv. 1964 (M. Munakata) ;1우, Fukushima, Oshima, 30. v. 1965 (M. Munakata) ;1우, Mt. Daisengen, Oshima, 9. vi. 1958 (M. Munakata). OKUSHIRI IS. :2우, 28. v. 1965 (M. Munakata).

Specimens other than the types : HONSHU : Asagishi, Iwate Pref. :1 우, 8. vi. 1975 (Y. Maeta);5우, 6. vi. 1979 (Y. Maeta); 20 우, 10. vi. 1981 (Y. Maeta); Ashiro, Iwate Pref. :1우, 18. v. 1975 (Y. Maeta);3우, 27. v. 1981 (Y. Maeta); 1 우, 16. vi. 1981 (Y. Maeta); 2 우, 18. vi. 1981 (Y.Maeta); Kuzakai, Iwate Pref. :5 우, 6. v. 1975 (Y. Maeta); 1 우, 28. v. 1976 (0. Tadauchi) ;1우, Nasu-Yumoto, Tochigi Pref., 22. v. 1975 (0. Tadauchi) ;1우,Funado, Nakajo, Niigata Pref., 9. iv. 1985 (K. Baba) ; Mt. Shinbo, Asahi, Niigata Pref. : 1 우, 3. v. 1983 (K. Baba) ;1우, 2. v. 1985 (K. Baba).

Type depository: The type is preserved in the collection of the Entomological Laboratory, Faculty of Agriculture, Kyushu University.

This species is named for the honor of Prof. S. F. Sakagami of Hokkaido University.

\section{Andrena (Andrena) apicata aino Tadauchi, H irashima et Matsumura, new subspecies}

(Figs. 8, 23, 38, 66-71, 94, Table 4) 

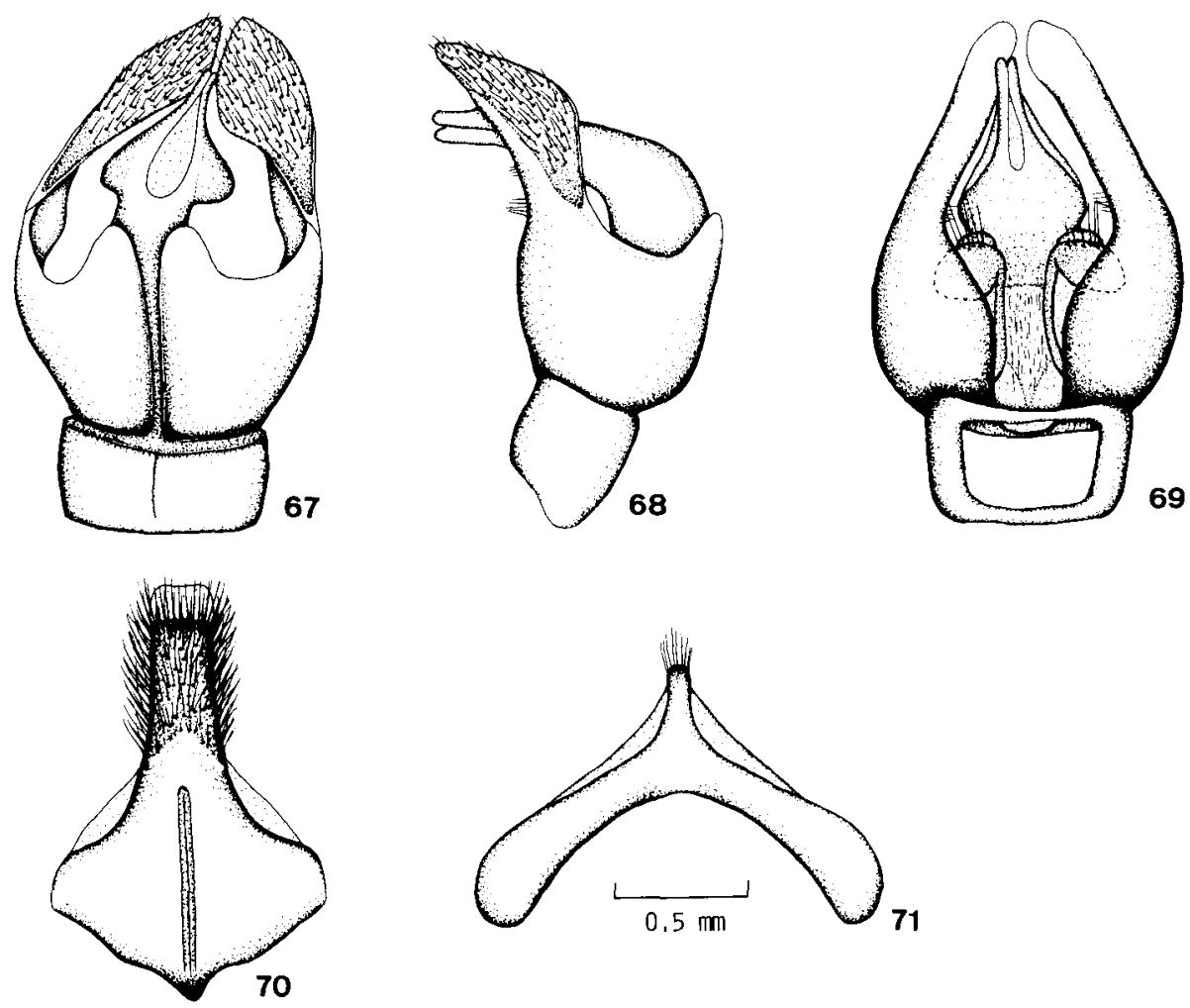

Figs. 67-71. Genital capsule and associated structures of Andrena (Andrena) apicata aino, new subspecies, 67 : dorsal view of genital capsule, 68 : lateral view of the same, 69: ventral view of the same, 70: 7th sternum, $71: 8$ th sternum.

Andrena (Andrena) sp. A, Usui et al., 1976, Res. Bull. Obihiro Univ., $10: 229$.

This species is recorded from Japan for the first time. This new subspecies is separable from the European Andrena apicata Smith by the hairs on the head and thorax sooty white, the metasomal terga 334 with complete, obscure, greyish fringes, the triangular area of the pygidial plate narrow, with indistinct punctures, and the hairs on the male metasomal tergum 1 sparse. It is also distinguished from the Kamtschatican Andrena apicata kamtschatica Alfken by the caudal fimbria fuscous, the tibial scopa brownish above, narrowly whitish below, the hind tibiae and tarsi reddish brown and the male mandible without a triangular projection near the base. At present, this new subspecies is known from Hokkaido where it is restricted to Obihiro city only. It flies early in spring and visits the flowers of Salix sp.

Female : Length 12.0-13.0 mm.

Integumental color: Flagellar segments beneath brownish ; posterior margins of metasomal terga reddish brown subhyaline.

Pubescence : Hairs on head and thorax long, dense ; those on clypeus dirty white 
basally, brownish apically; those on paraocular area, frons and genal area near eye fuscous; those on vertex mixed with fuscous; facial fovea blackish above, paler below ; hairs on thorax dirty white, shorter above, longer and intermixed with blackish ones laterally ; those on propodeum dirty white, intermixed with blackish hairs ; propodeal corbicula perfectly developed with well curled, long hairs anteriorly ; trochanteral and femoral floccus white ; tibial scopa rather small, not specially compact, composed of short hairs ; tibial scopa brownish above, narrowly whitish below ; hairs on metasomal tergum 1 long, terga 2-5 long, erect to suberect, each with a loose, obscure hair band on each posterior margin ; caudal fimbria brown.

Structure : Process of labrum small, transverse, well convex apically ; malar space about 1/4 times as long as base of mandible ; clypeus with basal half densely tessellate, apical half weakly tessellate, with shallow, dense, small punctures ; clypeus with a narrow, median, impunctate space ; mesoscutum and mesoscutellum densely tessellate with shallow, sparse, indistinct punctures ; propodeum shagreened ; enclosure ill defined, rugose on basal $1 / 4$, tessellate apically ; mesepisternum shagreened anteriorly, densely tessellate posteriorly ; metasomal terga densely tessellate, nearly impunctate; posterior depressions of terga broad, not well indicated.

Male : Length $9.5 \mathrm{~mm}$.

Integument\& color: Mandibles reddened apically ; flagellum brownish beneath ; posterior margins of metasomal terga reddish brown subhyaline.

Pubescence : Hairs on head dense, long, dull whitish ; those on clypeus dense, dull whitish ; those on thorax sparse, not long, dull whitish to pale yellowish, not mixed with fuscous ones; those on vertex mixed with fuscous ones; those on lower paraocular area and frons near eye fuscous ; those on propodeum dull whitish mixed with fuscous ones ; those on legs whitish except for tibiae and tarsi, which are covered with pale yellowish hairs ; those on metasomal terga not long, whitish ; posterior margins of terga 2-5 with obscure, whitish, hair bands ; tergum 6 whitish ; metasomal sterna 2-5 without long, curled hair fringes.

Structure : Mandible long, curved, without a basal projection ; malar space very short, about 1/6 times as long as base of mandible ; process of labrum small, slightly emarginate, smooth and shiny ; clypeus nearly flat, densely tessellate and also densely punctate all over, with punctures small ; genal area not distinctly angled behind ; flagellum 1 twice as long as wide, about twice as long as 2, which is as long as wide, and longer than 3 ; mesoscutum and mesoscutellum densely tessellate, indistinctly punctate ; propodeum shagreened ; enclosure of propodeum small, ill defined, rugose on basal $1 / 4$, tessellate apically ; mesepisternum shagreened with shallow punctures ; metasomal terga weakly tessellate, becoming smoother toward apical terga ; posterior depressions of terga broad, indistinct ; genitalia and associated structures as illustrated (Figs. 67-71).

Distribution : Japan (Obihiro, eastern Hokkaido). (Fig. 66)

Floral record: Nine females and 2 males have been collected on Salix sp. (Salicaceae).

Flight records: Female : mid April to mid May. Male : mid April.

Typematerial: Holotype female (Type No. 2573, Kyushu Univ.), Obihiro, Hokkaido, 29. iv. 1975 (M. Usui). Paratypes :1우, same data as holotype; samelocality 
and collector as holotype : 1 우, 30. iv. $1975 ; 1$ 우, 7. v. $1975 ; 1$ 우,13. v. $1975 ; 1$ 우, 12. iv. $1976 ; 2 \sigma^{7}, 13$. iv. 1976, 1 우, 28. iv. 1976 ; same locality as holotype, 2 우, 19. iv. 1967 (T. Nakaguchi).

Type depository : The type is preserved in the collection of the Entomological Laboratory, Faculty of Agriculture, Kyushu University. 